\title{
Three Decades of Customer Value Research: Paradigmatic Roots and Future Research Avenues
}

Journal of Service Research 2020, Vol. 23(4) 409-432 (C) The Author(s) 2020 Article reuse guidelines: sagepub.com/journals-permissions DOI: 10.1 I77//094670520948/34 journals.sagepub.com/home/jsr

(9)SAGE

\author{
Valarie A. Zeithaml' (D, Katrien Verleye ${ }^{2}$ (D), Isabella Hatak ${ }^{3}$, \\ Monika Koller ${ }^{4}$, and Alexander Zauner ${ }^{5}$
}

\begin{abstract}
The last three decades have witnessed a resurgence of research on the topic of customer value. In search of a comprehensive integration and analysis of this research-including conceptualization, operationalization, and measurement-we examined the myriad journal publications on the construct. We acknowledge that while some of the literature can be fully integrated, other parts are more difficult because they represent three different paradigms: positivist, interpretive, and social constructionist. We begin by briefly describing these three paradigms. Next, we detail the many studies representing the positivist paradigm, literature capturing customer value from just the customer's perspective and using deductive logic. We designate the second paradigm as interpretive, in that researchers are interested in understanding the subjective nature of customer value along with its emergence through inductive logic. The third paradigm, the social constructionist, frames customer value as emerging from value co-creation practices in complex ecosystems. Building upon the commonalities and differences among research studies stemming from the positivist, interpretive, and social constructionist paradigms, we propose how researchers can complement one another to move the customer value field forward.
\end{abstract}

\section{Keywords}

customer value, literature review, research agenda, positivist view, social constructionist view, interpretive view, customer perceived value, value co-creation

Confronted with demanding and well-informed customers, global competition, and unstable economies, delivering value to stakeholders and markets is more critical than at any time in the past. In board rooms around the globe, the conviction persists that all meaningful marketing activity must be directed at creating customer value (e.g., Leroi-Werelds 2019). From an academic perspective, interest and attention to the construct of perceived customer value emerged in the 1980s. Ever since that time, researchers reignited the search for its definition and measurement (e.g., Dodds and Monroe 1985; Hirschman and Holbrook 1982; Zeithaml 1988).

Throughout the 1990s and 2000s, the construct flourished in the management, organization, and marketing literatures. The conceptualization and measurement of customer value evolved rapidly, generating remarkable insights and challenging questions (e.g., Zauner, Koller, and Hatak 2015). An increasing number of contributions added to the complexity in understanding the type, measurement, and operationalization of customer value (e.g., Sánchez-Fernández, Iniesta-Bonillo, and Holbrook 2009).

Parallel to research endeavors to measure perceived customer value and its importance (e.g., Chiu et al. 2014; Sweeney and Soutar 2001), a growing number of researchers-often inspired by service-dominant logic (SDL) — aimed to provide insight into the value process and its emergence and management (e.g., Heinonen 2006; Kelleher et al. 2019). ${ }^{1}$

Meanwhile, efforts to review the customer value literature date from close to a decade back (e.g., Boksberger and Melsen 2011; Gallarza, Gil-Saura, and Holbrook 2011), some of which only consider business contexts while most studies focus on consumer contexts (see Web Appendix for an overview of the customer value literature in business contexts).

\footnotetext{
' Kenan-Flagler Business School, University of North Carolina at Chapel Hill, NC, USA

${ }^{2}$ Department of Marketing, Innovation and Organisation, Center for Service Intelligence, Ghent University, Belgium

${ }^{3}$ Swiss Research Institute of Small Business and Entrepreneurship (KMU-HSG), University of St. Gallen, Switzerland

${ }^{4}$ Department of Marketing, Institute for Marketing \& Consumer Research, WU Vienna, Austria

${ }^{5}$ Institute of Retailing, Sales \& Marketing, JKU Business School, Johannes Kepler University Linz, Austria
}

\section{Corresponding Author:}

Valarie A. Zeithaml, Kenan-Flagler Business School, University of North Carolina at Chapel Hill, Campus Box 3490, Chapel Hill, NC 27599, USA.

Email: valariez@unc.edu 
The present article focuses on customer value research in consumer markets, as considerable variation exists in the conceptualization of perceived customer value (an outcome as defined by the customer) that may partially relate to a lack of convergence among different philosophical paradigms (Becker and Jaakkola 2020). Divergent paradigms, with differing positions on the core elements of a construct are not in and of themselves problematic but may confuse researchers and create profound implications for practitioners (Brodie, Löbler, and Fehrer 2019). Recommendations to manage customer value, for instance, may vary from appeals to experiment with new products and services to calls for careful prediction of customer value, using comprehensive analysis and systematic procedures, before bringing new products or services to market.

For the productive evolution of customer value research, the field needs to recognize the different paradigms and explore opportunities to reconcile paradigmatic anomalies (Brodie, Löbler, and Fehrer 2019). As a result, the purposes of this article are to summarize, reflect on, and integrate extant philosophical views on customer value with the goal of moving toward a rigorous, novel, and relevant analysis of the construct that considers the similarities and differences. Specifically, this research presents the positivist, interpretive, and social constructionist paradigm and addresses the following research questions:

1. How did conceptualizations of perceived customer value reflecting the positivist, the interpretive, and the social constructionist view evolve over time?

2. What are the commonalities and differences among customer value research adopting positivist, interpretive, and social constructionist views?

3. How can the positivist, interpretive, and social constructionist views on customer value be reconciled to motivate future research and assist managers?

In this article, we first briefly overview the three paradigms. Next, we offer a more detailed discussion of both of the conceptual development and measures of customer value associated with the positivist perspective. The emphasis here is on the dimensionality, abstraction, and model taxonomy of the perceived customer value construct. By doing so, we echo current calls that accentuate the importance of properly establishing the validity of the construct capturing what researchers and practitioners intend to actually capture (Mochon and Schwartz 2020). Next, we provide a synopsis and in-depth reflections of the conceptual developments in customer value research reflecting the interpretive and social constructionist views, thereby showing a shift from individualistic to contextual conceptualizations and then from dyadic to systemic conceptualizations.

Our analysis of customer value research following the three paradigms suggests differences in foci, theoretical underpinnings, and methodological approaches, yet also demonstrates that complementarities exist. With a profound understanding of the customer view (customer perceived value [CPV]) and its properties as well as the process of value creation, the reconciliation of different paradigms has the potential to move the field forward in new and valuable ways. To do so, we propose a customer value framework in which we assemble evidence stemming from distinct research paradigms together and use this framework as inspiration for moving the whole field forward with specific directions for future applications in marketing, consumer behavior, and management. Our article offers insights for both research and practice - research for a more focused and coherent analysis of customer value and practice for the ability to act on the basis of more precise conclusions due to a more comprehensive understanding of customer value.

\section{Three Paradigms in Customer Value Research}

A paradigm provides the basis of assumptions about the nature of reality (ontology), the nature of knowledge about reality (epistemology), and the nature of ways to study reality (methodology). In the study of customer value, our systematic review found representation of three paradigms: positivist, interpretive, and social constructionist paradigms. Table 1 summarizes the different paradigmatic assumptions and thereby ontological, epistemological, and methodological aspects of customer value.

Perceived customer value research in the positivist paradigm evolved almost completely in the marketing discipline and reflects the traditional and familiar approach to research in the United States. The positivist paradigm contends that reality is objective and can be observed. Further, it assumes that researchers gain knowledge about a single reality by collecting and analyzing data in an objective way (Crotty 1998). Researchers start with theories, test them by observing objective reality, and use statistical methods to analyze data gathered through measurement. They therefore rely on deductive logic (Creswell and Poth 2018), typically using quantitative measurement.

Researchers adopting an interpretive paradigm of customer value focus on the subjective and situational experience between a subject (here, customers) and objects (here, products or services). In the interpretive tradition, researchers assume that the value of a product or service varies across customers and that subjective interpretations are crucial for understanding customer value because no single reality exists. Instead, reality can be interpreted in multiple ways (Creswell and Poth 2018). Consequently, researchers typically use approaches such as personal introspection, interviews, and observational methods, thereby adopting inductive logic to gain insight into customer value.

In line with the interpretive paradigm, social constructionists contend that customer value is interpreted subjectively but add that the social context gives rise to these interpretations. In fact, customer value is not only determined subjectively but is also socially constructed. As such, the social constructionist paradigm bridges the gap between the objective and the subjective perspective. Indeed, social constructionists contend that 
Table I. Comparison Among Positivist, Interpretive, and Social Constructionist Views of Customer Value.

\begin{tabular}{|c|c|c|c|}
\hline Assumptions & Positivist & Interpretive & Social Constructionist \\
\hline $\begin{array}{l}\text { How is reality known } \\
\text { (epistemology)? }\end{array}$ & $\begin{array}{l}\text { Reality can be observed and measured by } \\
\text { human beings in an objective way }\end{array}$ & $\begin{array}{l}\text { Reality is interpreted by human beings in a } \\
\text { subjective way }\end{array}$ & $\begin{array}{l}\text { Reality is constructed by } \\
\text { human beings as they } \\
\text { engage with the world } \\
\text { they are interpreting }\end{array}$ \\
\hline $\begin{array}{l}\text { What is the approach to } \\
\text { inquiry } \\
\text { (methodology)? }\end{array}$ & $\begin{array}{l}\text { Focus on capturing customer value by } \\
\text { constructing and/or using perceptual } \\
\text { measures through survey and } \\
\text { experimental research using a } \\
\text { deductive logic }\end{array}$ & $\begin{array}{l}\text { Focus on understanding the emergence of } \\
\text { customer value by means of personal } \\
\text { introspection, interviews, and } \\
\text { observations, thereby adopting an } \\
\text { inductive logic }\end{array}$ & $\begin{array}{l}\text { Focus on understanding the } \\
\text { construction of customer } \\
\text { value, thereby adopting an } \\
\text { abductive logic }\end{array}$ \\
\hline $\begin{array}{l}\text { What is value? } \\
\text { Including conceptualiza- } \\
\text { tion, dimensionality, level } \\
\text { of abstraction, and model } \\
\text { taxonomy }\end{array}$ & $\begin{array}{l}\text { Value-as-outcome: Value as a judgment or } \\
\text { evaluation of an experience or } \\
\text { interaction with an object of any type } \\
\text { (often including trade-off between what } \\
\text { customer gives and gets-Zeithaml } \\
\text { 1988) } \\
\text { - Shift from unidimensional } \\
\text { conceptualizations with a focus on } \\
\text { rational/cognitive components to } \\
\text { multidimensional conceptualizations } \\
\text { in which emotional/social components } \\
\text { are also considered } \\
\text { - Shift from concept comprising } \\
\text { different (first order) dimensions to a } \\
\text { higher order (overall) construct }\end{array}$ & $\begin{array}{l}\text { Value as a (preference) experience } \\
\text { emerging from sensemaking } \\
\text { - Multidimensional conceptualizations } \\
\text { with rational/cognitive and emotional/ } \\
\text { social dimensions } \\
\text { - Higher order conceptualizations } \\
\text { incorporating cost-benefit trade-off } \\
\text { idea coexist with first-order } \\
\text { conceptualizations focusing on } \\
\text { benefits } \\
\text { - Shift from individualistic to contextual } \\
\text { conceptualization of customer value }\end{array}$ & $\begin{array}{l}\text { Value is co-created during } \\
\text { value co-creation } \\
\text { practices (cf. value-as- } \\
\text { process) } \\
\text { - Shift from dyadic to } \\
\text { systemic } \\
\text { conceptualization of } \\
\text { customer value }\end{array}$ \\
\hline
\end{tabular}

phenomena - such as customer value - are "contingent upon human practices, being constructed in and out of interaction between human beings and their world, and developed and transmitted within an essentially social context" (Crotty 1998 , p. 42). Through social interactions, individuals internalize institutionalized norms, values, and assumptions that endow their interpretations of phenomena with meaning (Koskela-Huotari and Siltaloppi 2020). To endow their interpretations of customer value with meaning, researchers canin accordance with the social constructionist paradigm-go back and forth between empirical data and the customer value literature, which reflects an abductive logic.

We also show in Table 1 a summary of the conceptualization, dimensionality, and level of abstraction in each of the paradigms. In the sections that follow, we detail how each of these paradigms is reflected in the CPV and customer value literatures, thereby delineating how research inspired by the three different paradigms evolved over time.

\section{Positivist View of Customer Value}

Table 2 provides an overview of customer value research in the positivist tradition, most of it referring to CPV. As this research evolved over time, it reflected a shift from unidimensional to multidimensional to higher order conceptualizations.

\section{Phase I-The Unidimensional Conceptualization}

Early research on CPV focused on the quality-price relationship (Dodds and Monroe 1985; Monroe and Chapman 1987), a view that led to the understanding of value as a "cognitive trade-off between perceptions of quality and sacrifice" (Dodds, Monroe, and Grewal 1991, p. 308). Advancing the model proposed by Dodds and Monroe (1985) and using means-end theory, Zeithaml (1988) proposed that CPV is a higher order abstraction and that a distinction exists among objective attributes of a product or service and subjective outcomes or perceptions of those attributes, a qualification that underlies later customer value conceptualizations.

During this early stage of development, the focus was on CPV, which was largely viewed as a unidimensional construct - a single overall latent construct measured by a selfreported item or set of items. Although this unidimensional construct might be influenced or produced by multiple antecedents (e.g., perceived quality), it was not viewed as an aggregated concept formed from several components (SánchezFernández and Iniesta-Bonillo 2007).

Until the beginning of the 2000s, myriad studies (e.g., Brady and Robertson 1999; Monroe and Chapman 1987; Sweeney, Soutar, and Johnson 1999) adopted the unidimensional conceptualization based directly on the pioneering works. Other studies linked to them indirectly (e.g., Cronin, Brady, and Hult 


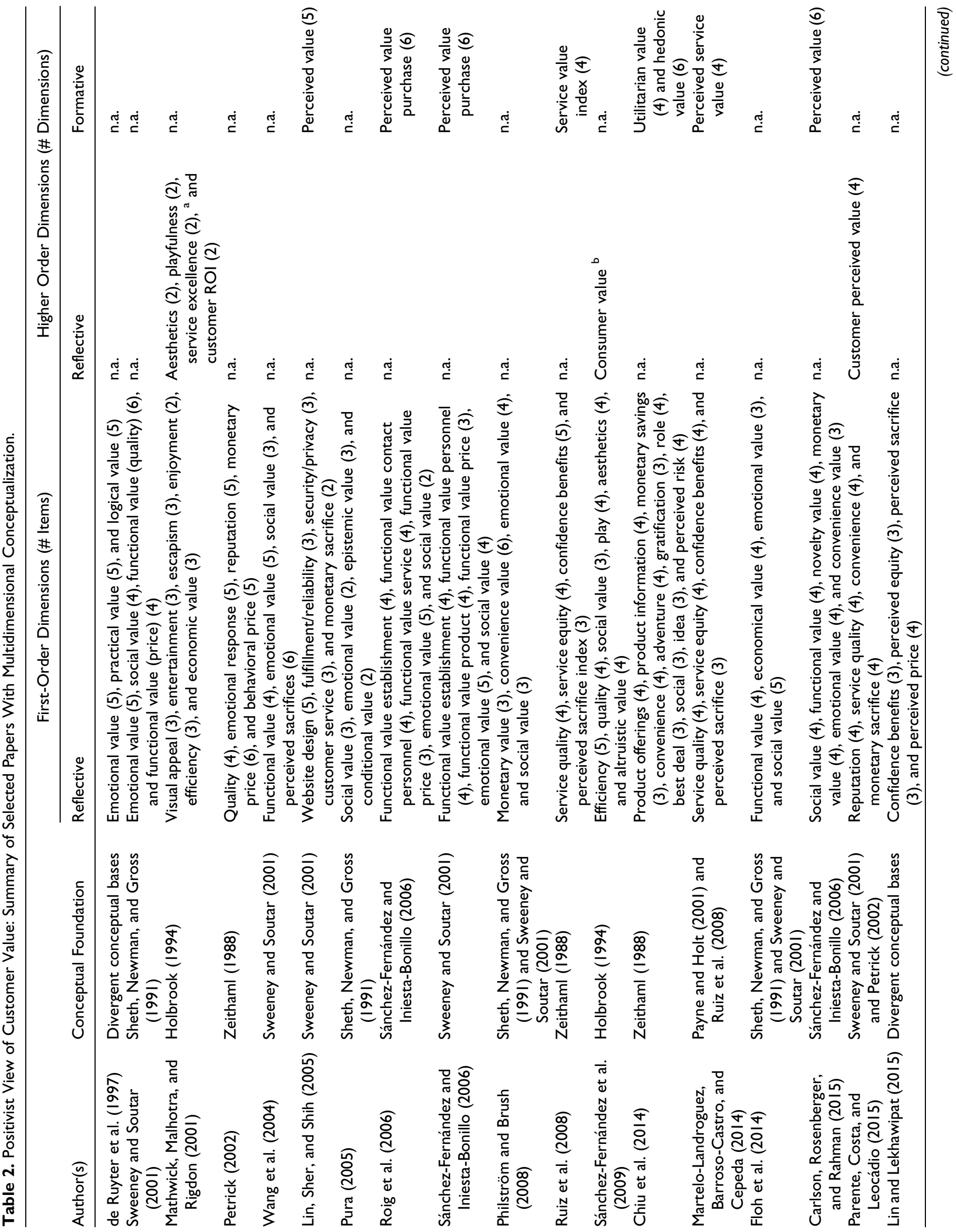




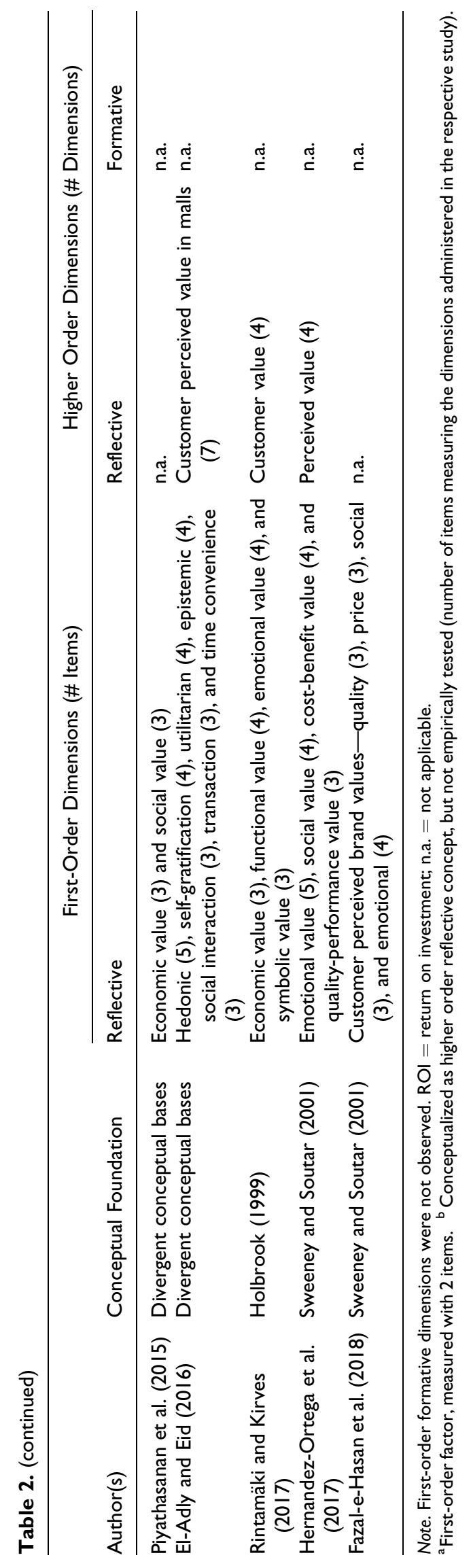


2000; Cronin et al. 1997; Gallarza and Gil-Saura 2006). Overall, at this stage of conceptual development, customer value perceptions were viewed as resulting from an evaluation of the benefits and sacrifices associated with a product or service (e.g., Dodds and Monroe 1985; Graf and Mass 2008; Zeithaml 1988). Value was based on the concept of a trade-off, an intuitive calculation, or give-versus-get, which was associated with the economic theory of utility.

To summarize Phase I, the unidimensional perspective focuses on the economic and cognitive aspects of CPV: Customers behave rationally to maximize the utility of their choices (Sánchez-Fernández and Iniesta-Bonillo 2007) and account for alternative market offerings (Gale and Wood 1994). Although the unidimensional conceptualization was dominant only until the end of the 1900 s, more recent studies continue to use it with other high-level abstract constructs such as customer satisfaction (e.g., Zboja, Laird, and Bouchet 2016).

\section{Phase II-The Multidimensional Conceptualization}

Since the 1990s, CPV has been predominantly viewed as a multidimensional construct because consumption experiences involve more than one aspect of value simultaneously (e.g., Babin, Darden, and Griffin 1994; Holbrook 1994; Sheth, Newman, and Gross 1991). In fact, Hirschman and Holbrook (1982) had earlier argued for an experiential perspective of customer value that included not only utilitarian aspects but also symbolic, hedonic, and aesthetic aspects in consumption.

Considering the critique of the unidimensional conceptualization being too simplistic (Sánchez-Fernández et al. 2009), arcane (Huber, Herrmann, and Henneberg 2007), and narrow (Mathwick, Malhotra, and Rigdon 2001), Phase II CPV research extended beyond cognitive evaluations alone to include emotional and social aspects relating to the products or brands under scrutiny. As a result, $\mathrm{CPV}$ was characterized as a multidimensional construct comprising attributes or dimensions that captured consumers' holistic or multifaceted value perceptions (e.g., Babin, Darden, and Griffin 1994; Sheth, Newman, and Gross 1991). By introducing the theory of consumption values, the pioneering approach of Sheth, Newman, and Gross (1991) extended the purely functional or economic propositions described in Phase I and explicitly posited (but did not test) five independent customer value dimensions (see Table 3). These dimensions contribute in varying degrees to customers' consumption decision depending on the situation and the offering under consideration. For example, functional and social value dominate the decision over whether to use filtered or unfiltered cigarettes whereas emotional value is key to the decision to smoke.

Another multidimensional conceptualization was advocated by Holbrook (1994, 1999), who defined customer value "as an interactive relativistic preference experience" (Holbrook 1994, p. 27), and proposed a typology of consumer value consisting of three dichotomies: (1) extrinsic versus intrinsic, (2) selforiented versus other-oriented, and (3) active versus reactive. When these criteria combined, eight different value types emerged. According to this understanding, the value dimensions usually occurred together in varying degrees, thereby integrating both cognitive and affective aspects.

The measurement instrument PERVAL (Sweeney and Sou$\operatorname{tar} 2001$; for applications, see, e.g., Pura 2005; Wang et al. 2004) comprises four different and interrelated value dimensions: (1) emotional; (2) social, a market offering's ability to enhance social self-concept; (3) economic, the output/input ratio; and (4) functional, the utility a market offering provides. PERVAL's reliability and validity were established in both prepurchase and postpurchase contexts. In addition to Sheth, Newman, and Gross (1991) and Sweeney and Soutar (2001), Petrick (2002) developed a multidimensional conceptualization (see Table 2), which - after successful empirical testing in the tourism industry - was shown to be a valuable tool for the measurement of CPV (Oliver 2010).

Therefore, in Phase II, CPV had both a cognitive and affective nature, comprising rational and emotional/hedonic dimensions (see also Sweeney and Soutar 2001). This wide adoption of the multidimensional approach echoes the growing relevance of emotions in decision making (Sánchez-Fernández et al. 2009) as supported by the cognition-affective-conative (behavior) paradigm.

While Phase II scholars agreed on the need for a multidimensional conceptualization, they disagreed on the composite dimensions depending on the specific contexts researched or industries studied. For instance, El-Adly and Eid (2016) measured CPV in shopping malls with a second-order construct named MALLVALL consisting of seven reflective dimensions (see Table 2). Parente, Costa, and Leocádio (2015) generalized that single industries needed to develop specific measurement instruments for $\mathrm{CPV}$ following a comprehensive scale development process. Along these lines, Varshneya and Das (2017) developed an instrument for measuring experiential value, modeled as a second-order factor comprising four distinct experiential value dimensions. In another example of a multidimensional understanding, drawing not only from one source but also including different sources for the single value types, Oyedele and Simpson (2018) added convenience value to the previous set of dimensions in the context of streaming apps. In this line, Previte et al. (2019) added altruistic value as an additional dimension when investigating the role of emotional value for reading and giving the scale Electronic Word of Mouth (WOM) in regard to blood donation. Moreover, Gallarza et al. (2017) establish a Service Value Scale based on Holbrook's (1999) typology, modeled as a third-order formative construct.

\section{Phase III-The Higher Order Conceptualization}

Phase III built on Phase II but elevated the conceptualization and measurement of CPV to a higher level. Research also shifted from defining and operationalizing to actually testing and applying CPV in relation to diverse constructs and realworld situations. The theoretical construct of CPV was either reflected in or composed of its respective lower level indicators or dimensions (Lin, Sher, and Shih 2005). This higher order 
conceptualization raised the question of whether formative (aggregate composite) or reflective (latent factor) indicators should be considered (e.g., Baxter 2009; Lin, Sher, and Shih 2005; Ruiz et al. 2008). As with all scales, first-order dimensions are predominantly conceptualized as reflective factors, being interrelated and reflected by manifest indicators or measures (i.e., items). For second-order levels, arguments for both the reflective and formative conceptualizations have been proffered, extending the conceptual debate surrounding this issue initially raised by scholars such as Jarvis, MacKenzie, and Podsakoff (2003). For example, Sheth, Newman, and Gross's (1991, p. 163) argumentation that the value dimensions are independent, "relating additively and contributing incrementally to choice," suggested a formative CPV conceptualization. In contrast, Sweeney and Soutar's (2001) proposition that the value dimensions are dependent and hence interrelated indicated a further specification of the concept as a second-order reflective model. Recent publications follow this reasoning by modeling perceived value as a second-order reflective construct (see Table 2). For instance, Rintamäki and Kirves (2017) modeled CPV as second-order reflective to address multicollinearity between individual dimensions of value.

We draw the following conclusions from a selection of recent studies adopting a multidimensional value conceptualization. To begin with, the first-order dimensions are exclusively conceptualized as reflective factors (see Table 1). Consequently, in these cases, the different CPV dimensions (e.g., social and functional value) are interrelated and reflected by manifest indicators or measures (i.e., items), which are in principle interchangeable. Hence, the direction of causality goes from the concept to the items (Jarvis, MacKenzie, and Podsakoff 2003). Second, studies conceptualizing CPV as a higher order construct employ either reflective (e.g., Mathwick, Malhotra, and Rigdon 2001; Rintamäki and Kirves 2017) or formative (e.g., Carlson, Rosenberger, and Rahman 2015; Jiang, Luk, and Cardinali 2018; Ruiz et al. 2008) propositions, with some tendency toward the latter.

\section{Reflections on the Positivist View}

First, although there is a stronger empirical basis for the unidimensional conceptualization of CPV, mainly due to its simpler implementation and assessment (Sánchez-Fernández and Iniesta-Bonillo 2007), the multidimensional proposition has gained wider acceptance (see also Gallarza et al. 2017; Leroi-Werelds 2019; Leroi-Werelds et al. 2014). Yet, the dimensionality of the multidimensional conceptualization, as well as its conceptual dimensions, remains contested (Gallarza, Gil-Saura, and Holbrook 2011). CPV has been measured with a varying number of dimensions, ranging from 2 (Piyathasanan et al. 2015) to 6 (Mathwick, Malhotra, and Rigdon 2001), to as many as 11 (Chiu et al. 2014). This diversity is caused by studies' differing conceptual foundations (Holbrook 1994; Sheth, Newman, and Gross 1991; Sweeney and Soutar 2001). On the other extreme, there are also studies choosing only one dimension (e.g., Koronaki, Kyrousi, and Panigyrakis 2018).
Because CPV has been applied in diverse contexts (tourism, industrial clusters, education, etc.), the proposed/required dimensionality (Gallarza et al. 2017; Gallarza, Gil-Saura, and Holbrook 2011) differs. Nevertheless, the importance of conceptualizing CPV along cognitive and emotional dimensions is supported by neuroscience that underlines the predominant role of cognition and emotions in forming individuals' preferences and perceptions (e.g., Verhulst et al. 2019).

Second, a multidimensional conceptualization requires a comprehensive discussion on the level of abstraction and modeling of the latent variable (Zauner, Koller, and Hatak 2015). Although the variety of solutions presented in this context is high, a trend in the level of abstraction has materialized. To analyze how CPV coexists with or influences other concepts, an abstract or higher order conceptualization is necessary (e.g., Gallarza, Gil-Saura, and Holbrook 2011; Lin, Sher, and Shih 2005; Ruiz et al. 2008; Zeithaml 1988). Therefore, in addition to conceptualizing CPV as a concept comprising different (first order) dimensions, a higher order (overall) CPV construct, or several such constructs, is advocated. As a result, the relational disposition of CPV is clarified and its practical and scientific relevance increased. Such a conceptualization also facilitates the investigation of perceived value on a more abstract level, analyzing both the customer and the firm perspective simultaneously (Martelo-Landroguez, Barroso-Castro, and Cepeda 2014).

Third, when it comes to model taxonomy, we conclude that first-order dimensions are predominantly conceptualized as reflective factors, thus being interrelated and reflected by manifest indicators or measures (i.e., items). Studies conceptualizing CPV as a higher order construct employ either reflective or formative propositions, with some tendency toward the latter. Depending on the number of first- and second-order factors modeled, the levels vary between two and three. When value is modeled on higher than two levels, an index of the secondorder factors is formed (see, e.g., Gallarza et al. 2017). However, against the background that a formative model of CPV constitutes a summary measure in the form of a structural model, further research regarding the higher order conceptualization of (customer perceived) value seems worthwhile.

\section{Interpretive View of Customer Value}

Table 3 summarizes key papers on customer value representing the interpretive perspective. These papers reflect a shift from an individualistic to a contextual perspective, as detailed in the subsequent paragraphs.

\section{Phase I-Individualistic Conceptualization}

Zeithaml (1988) paved the way for an individualistic conceptualization by arguing that value is more idiosyncratic and personal than quality and is therefore a higher level concept than quality. A number of subsequent studies - such as Heinonen (2006) and Seraj (2012) - relate their interpretive work to the 1988 conceptualization of Zeithaml. By defining customer 


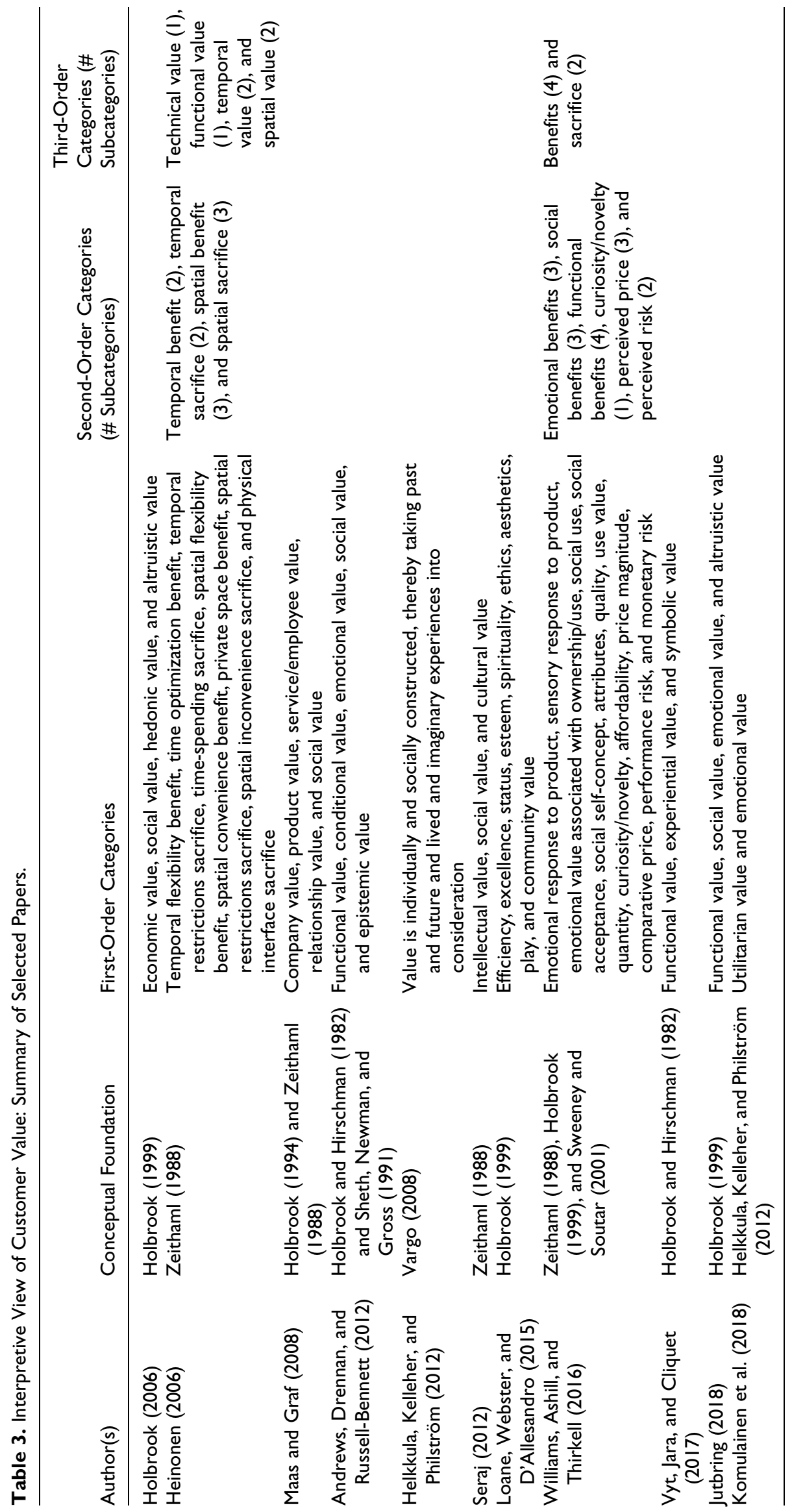


value as a relativistic preference experience emerging in interactions between a subject (e.g., consumer) and an object (e.g., product or service), Holbrook $(1994,1999,2006)$ advanced the individualistic perspective on customer value. Indeed, Holbrook (2006) contends that individual customers experience value in interactions with an object that they compare with interactive experiences with other objects. Because these experiences are subjective and situational, this conceptualization of customer value is experiential or phenomenological in spirit (Holbrook 2006; Holbrook and Hirschman 1982). This spirit is also present in Vargo and Lusch's (2008) revisions of the foundational premises of SDL, as they contend that "value is always uniquely and phenomenologically determined by the beneficiary" (p. 9).

As shown in Table 2, several customer value publications are positioned relative to the experiential or phenomenological perspective. Although Holbrook (2006) proposed subjective personal introspection as an appropriate method, this method has not been implemented by other researchers adopting an experiential or phenomenological perspective. Instead, most of these researchers opted for interviews to gain insight into the subjective and situational nature of customer value (e.g., Jutbring 2018; Maas and Graf 2008). Notable exceptions are the diary study of Williams, Ashill, and Thirkell (2016) and the netnographic study of Loane, Webster, and D'Allesandro (2015). Interestingly, all aforementioned studies identified different value dimensions and contended that their relative importance varies across customers (e.g., Andrews, Drennan, and Russell-Bennett 2012; Maas and Graf 2008) and/or situations (e.g., Maas and Graf 2008).

\section{Phase II-Contextual Conceptualization}

Building upon the experiential or phenomenological view on customer value, Helkkula, Kelleher, and Philström (2012) coined the term value-in-experience (VALEX). As such, these authors pointed out that customers make sense of value in the experience using subjective inner thoughts necessitating interpretive research methods. Specifically, Helkkula, Kelleher, and Philström (2012) proposed the event-based narrative inquiry technique (EBNIT) where customers can, spontaneously and in an unsolicited naturalistic fashion, reflect on the possible meaning of their experiences and co-constructs this meaning with the interviewer.

As illustrated by EBNIT, an important difference with the individualistic perspective of customer value is attention to the social context in which subjective inner thoughts emerge. Helkkula, Kelleher, and Philström (2012) asserted that inner thoughts reflect not only individual but also socially constructed preferences, resulting in the proposition that VALEX is both individually intrasubjective and also socially intersubjective. In other words, customer value is dependent on the way in which other market actors - such as other customers and firms-perceive value. In line with this view, researchers explored value not only in direct interactions with product and service providers but also in interactions with other market actors. By doing so, Komulainen et al. (2018) showed that the role of single product and service providers - here, banks - was limited and dependent on other economic and social actors. The extent to which these actors advanced customers' ways of life was considered more important than their experiences with specific service providers or brands. As such, this evidence suggests that customer value emerges in networks or systems of economic and social actors, another foundational premise of SDL (Vargo and Lusch 2008).

\section{Reflections on the Interpretive View}

In the interpretive tradition, unlike in the positivist view, no shift occurs from unidimensional to multidimensional conceptualizations. Instead, interpretive researchers identify multiple dimensions varying from three (e.g., Seraj 2012) to nine (e.g., Loane, Webster, and D'Allesandro 2015). In terms of similarity, however, researchers in the interpretive tradition providelike most positivist researchers-evidence for emotional and/ or social dimensions of customer value (see Table 3 for a detailed overview of the dimensions). One notable exception is Heinonen's (2006) study on customer perceived e-service value, but even this study calls for research on the emotional, cultural, and social aspects of e-service value. The attention to nonrational aspects is not surprising, as several researchers in the positivist tradition also relied on the work of Holbrook (1994, 1999).

In a few studies with three- and four-dimensional conceptualizations of customer value, researchers also observe subdimensions (e.g., Heinonen 2006). With regard to the higher order conceptualizations of customer value, benefits and sacrifices/costs often act as higher order dimensions with different types of benefits and sacrifices/costs as lower order dimensions in interpretive research (e.g., Williams, Ashill, and Thirkell 2016). These higher order conceptualizations relate to the trade-off idea where customers weigh benefits and costs (e.g., Zeithaml 1988). This observation suggests that interpretive researchers are, despite their acknowledgment of multiple realities, never completely uninformed about prior work (Gioia, Corley, and Hamilton 2013). Indeed, the immense popularity of a number of customer value papers-including but not limited to Zeithaml (1988) — may induce a confirmation bias.

Furthermore, not all interpretive studies reported in this section adopt a pure inductive logic. Instead, some researchers use existing conceptualizations of customer value as a starting point for gathering and/or analyzing data and adapt these conceptualizations based upon their own research (e.g., Jutbring 2018). Additionally, researchers - such as Heinonen (2006) and Williams, Ashill, and Thirkell (2016) — adopt an abductive logic meaning that they shift back and forth between empirical data from customers and the customer value literature. These researchers even engage in co-constructing perceived value with customers, which fits with the social constructionist paradigm described next. 


\section{Social Constructionist View of Customer Value}

Table 4 summarizes key papers in the social constructionist paradigm, which indicate a shift from a dyadic to a systemic perspective as detailed in this section.

\section{Phase I-Dyadic Conceptualization}

In the social constructionist tradition, researchers focus on the interactive nature of customer value, which is consistent with the conceptualization of customer value as a preference experience resulting from interactions with specific objects in the interpretive tradition. Unlike interpretive conceptualizations, however, social constructionists emphasize that customers co-construct these perceptions in their interactions with other economic and social actors. As shown in Table 4, several social constructionist conceptualizations rely on early contributions to SDL where researchers avowed the active role that customers played in the creation of value, thereby affecting the determination of value. Indeed, researchers claimed that value was determined by customers as "value-in-use" as they interacted with service providers to integrate resources (Grönroos and Gummerus 2014; Vargo and Lusch 2004). They held that co-creation, resource-integrating practices between customers and service providers, was necessary for value to be experienced and/or perceived by customers (Vargo and Lusch 2004). This conceptualization signifies social constructionism and differentiates it from the other paradigms: Customer perceptions are contingent upon value co-creation in interactions with service providers.

Most studies that built upon SDL centered on the process of co-creating value (Brodie, Löbler, and Fehrer 2019), but a few studies also incorporated customer perceptions as in CPV. Plewa et al. (2015), for instance, hold that "what customers create or co-create (a process) results in perceived value (a perception)" (p. 573). Their research focused on value perceptions in interactions with financial service providers. Their multidimensional conceptualization of $\mathrm{CPV}$ was found to relate to the customer (e.g., lifestyle costs), the provider (e.g., expertise value), and the interaction (e.g., relationship value). Each of these value perceptions was - in line with hierarchical conceptualizations of customer value in the positivist and interpretive tradition-also classified as a perceived benefit (e.g., relationship value) or a perceived cost (e.g., lifestyle costs) of interacting with financial service providers. Beirão, Patrício, and Fisk (2017) advanced the dyadic perspective on customer value by a case study in the health care sector. This study showed that interactions between customers and service providers may - as proposed by Vargo and Lusch (2011) — occur at the micro-level (e.g., individual health and well-being), the meso-level (e.g., patient base well-being), and the macrolevel (e.g., population well-being). By proposing value outcomes at different levels of aggregation, these researchers incorporated a systemic element in the customer value conceptualization.

\section{Phase II-Systemic Conceptualization}

The systemic conceptualization of value emphasizes that value co-creation extends beyond dyadic interactions between customers and service providers. Building upon more recent contributions to SDL, researchers increasingly recognize that customers are embedded in systems of social and economic actors engaged in integrating resources and exchanging services (Brodie, Löbler, and Fehrer 2019). In these service (eco)systems, a multitude of resource-integrating actors at different levels of aggregation - such as individuals, organizations, sets of organizations, and other stakeholders - engage in mutual value creation through service exchanges (Akaka and Vargo 2015; Chandler and Vargo 2011).

Adopting a systemic view on the creation of value, Figueiredo and Scaraboto (2016) contend that the value created by actors in systems undergoes changes of form. Drawing from their ethnographic research on "geocatching," these authors show that value may emerge as a potential condition that afterward acquires defined properties. The assessment of these properties denotes value outcomes of various types, such as hedonic, epistemic, and linking value, which in turn affect how other system actors assess value. In this context, the assessment of value is an ongoing and dynamic process for actors in a system, which then affects how other system actors assess value. In a similar vein, Kelleher et al. (2019) investigate how value dynamically emerges from value co-creation practices in complex systems such as collective consumption contexts. Specifically, these authors unravel the complex interplay between value for the individual and collective value cocreation practices affected by value-enhancing mechanisms (participation access and signposting) and value-constraining mechanisms (consumer heterogeneity conflicts and rigidity).

During value co-creation in complex systems, Akaka and Vargo (2015) point out that resource-integrating actors are connected not only through direct interactions but also through institutional arrangements, defined as sets of humanly devised rules, norms, and beliefs. These institutional arrangements are key to the understanding of the creation of value in service ecosystems because they enable and constrain value cocreation (Vargo and Lusch 2016). Building upon the importance of institutional arrangements, Blocker and Barrios (2015, p. 265) made a distinction between habitual value defined as "the everyday value that organizations offer to satisfy situational and domain-specific needs in a marketspace" and transformative value defined as "a social dimension of value creation that generates uplifting change for greater well-being among individuals and collectives." Transformational value emerges - in contrast to habitual value - when actors become conscious of their roles in reproducing institutional arrangements and start challenging these arrangements by exerting control over the historical, cultural, and social contexts in which they are enmeshed.

The aforementioned work suggests that actors are not only embedded in historical, cultural, and social contexts but also shape these contexts in which value is created through their 


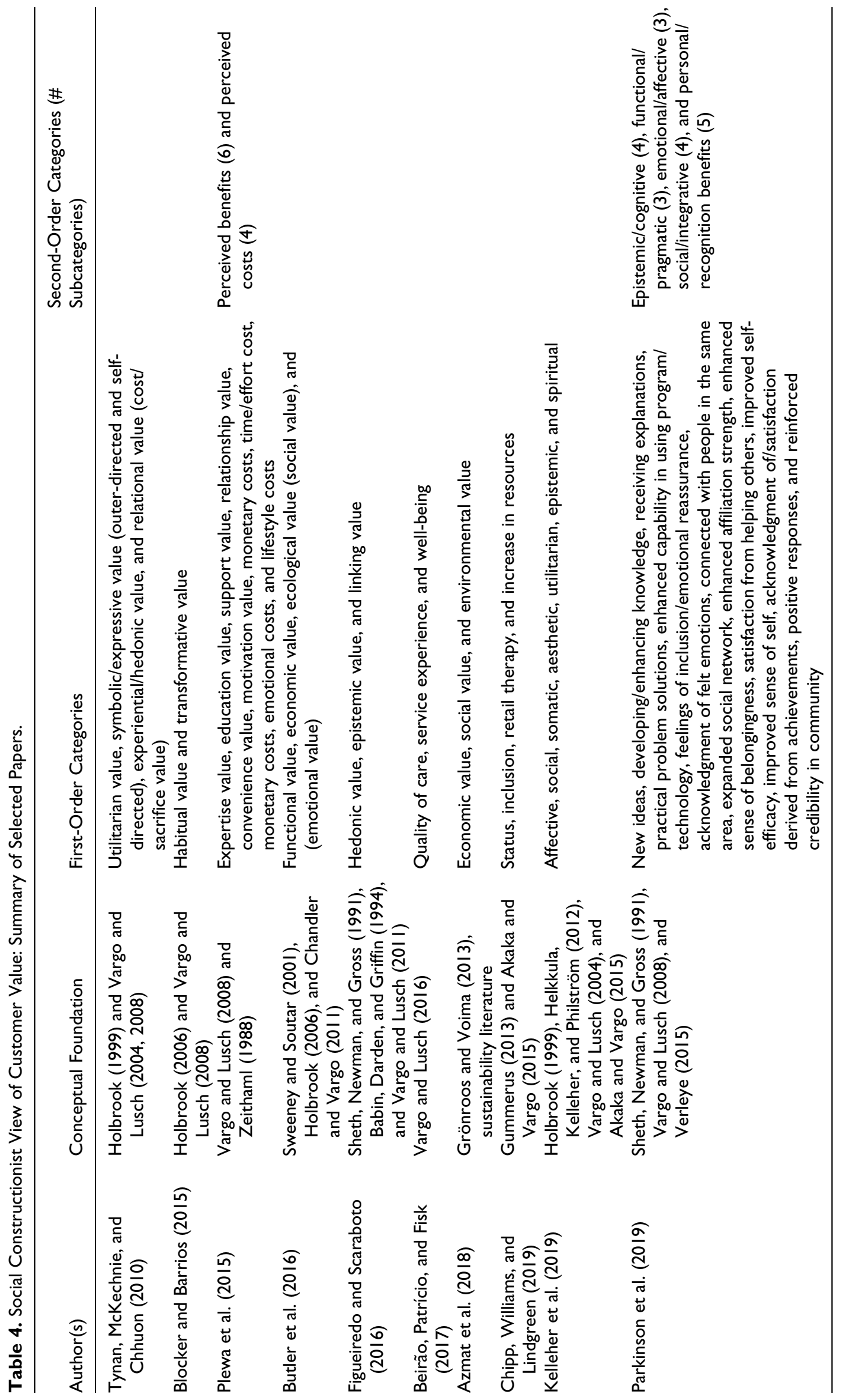


agency. By emphasizing actors' agency, this research also conforms to the social constructionist view.

\section{Reflections on the Social Constructionist View}

A pivotal similarity among the positivist, interpretive, and social constructionist research stream relates to the multidimensional conceptualizations of customer value. Indeed, Table 4 shows that research in the social constructionist tradition revealed between 2 and 19 dimensions of customer value. In line with the hierarchical conceptualizations of customer value in the positivist and interpretive research stream, other researchers also build on the work of Zeithaml (1988) and Verleye (2015) to classify the dimensions in broader categories (see, respectively, Plewa et al. 2015 and Parkinson et al. 2019), thereby representing abductive research logic.

A similarity between the interpretive and social constructionist research stream involves the emphasis on the interactive nature of customer value. In the interpretive tradition, customer value refers to a preference experience resulting from interactions with specific objects. The social constructionist conceptualization, on the other hand, contends that customer value perceptions emerge in interactions with specific service providers (Phase I-dyadic conceptualizations) and/or complex service ecosystems (Phase II-systemic conceptualizations).

The social constructionist view also differs from the interpretive view by its emphasis on the active role that customers play in interactions with other economic and social actors. More particularly, customers are presented as (co-)creators of value. Following the importance of value co-creation, researchers incorporating elements from the social constructionist view-such as Beirão, Patrício, and Fisk (2017) and Kelleher et al. (2019) —often investigate not only customer value (cf. value-as-outcome) but also the emergence of these value perceptions in interactions with other actors and hence value co-creation (cf. value-as-process). In fact, several social constructionist researchers only consider value co-creation from a process perspective, thereby relying on SDL. The increasing popularity of SDL may thus explain why customer value has received less research attention in recent review studies than value co-creation.

Interestingly, the impact of SDL is not limited to increased attention to value co-creation. Indeed, SDL advancements also inform the shift from a dyadic to a systemic perspective. Moreover, this shift in the social constructionist tradition exhibits some similarities with the shift from an individualist to a contextual perspective in the interpretive tradition. Indeed, SDL advancements have inspired researchers in the interpretive and social constructionist tradition to consider the historical, social, and cultural contexts in which value co-creation takes place (Vargo and Lusch 2008, 2016). In the social constructionist tradition, however, researchers also recognize that actors can shape the historical, cultural, and social contexts through value co-creation in service ecosystems.

Building upon the assertion that value perceptions emerge from participation by customers and optionally other actors in socioculturally determined value co-creation practices (Akaka and Vargo 2015), a number of researchers engaged in exploring these value co-creation practices. Some of these researchers even bridge the positivist and social constructionist paradigms by developing scales to capture value co-creation (e.g., Ranjan and Read 2016) and value co-creation behaviors (e.g., Tommasetti, Troisi, and Vesci 2017). As such, these researchers pave the way for research on the drivers and consequences of value co-creation behaviors in the positivist tradition (e.g., Waseem, Biggeman, and Garry 2018).

\section{Three Paradigms as Impetus for Five Research Avenues}

Figure 1 illustrates our customer value framework that reconciles the key elements of the positivist, interpretive, and social constructionist conceptualizations (see Note to conceptual elements in the figure for explanation of the paradigms to which they relate). As some conceptual elements relate to more than one paradigm while others are unique to a specific paradigm, this figure emphasizes similarities and differences among the three paradigms. Meanwhile, Figure 1 also shows that conceptual elements can be categorized in five groups (see ovals in which conceptual elements are embedded). First, "who" describes the source of customer value, as researchers have pointed out that perceptions can be individualistic, contextual, or both. Second, "how" involves the methodological approaches to study value, as some researchers emphasized their perceptual nature while others stressed the experiential or co-created nature. Third, "what" denotes the dimensionality, abstraction, and taxonomy of customer value. Fourth, "where and when" designates the situations where customer value emerges, as some researchers pay little attention to the interactive nature of customer value (individual) while interactions are a crucial element for others (dyad and ecosystem). Finally, "why" delineates the nomological network in which customer value emerges and matters. This categorization of conceptual elements stemming from the positivist, interpretive, and social constructionist traditions show convergence in terms of "what" (acknowledgment of multidimensional nature of customer value), "when/where" (recognition that customer value emerges in interactions with other actors), and "why" (appreciation for the importance of customer value). Paradigmatic divergence occurs with regard to "who" (making abstraction of individual and contextual sources of customer value in positivist tradition vs. embracing these sources of customer value in interpretive and social constructionist tradition) and "how" (focus on value perceptions in positivist tradition, focus on value experiences in interpretative tradition, and focus on value co-creation in social constructionist tradition). These similarities and differences in terms of "who," "how," "what," "when/ where," and "why" are translated in five research avenues, which are detailed in the next sections. Table 5 summarizes these research avenues, while Table 6 lists sample research questions for each research avenue. 


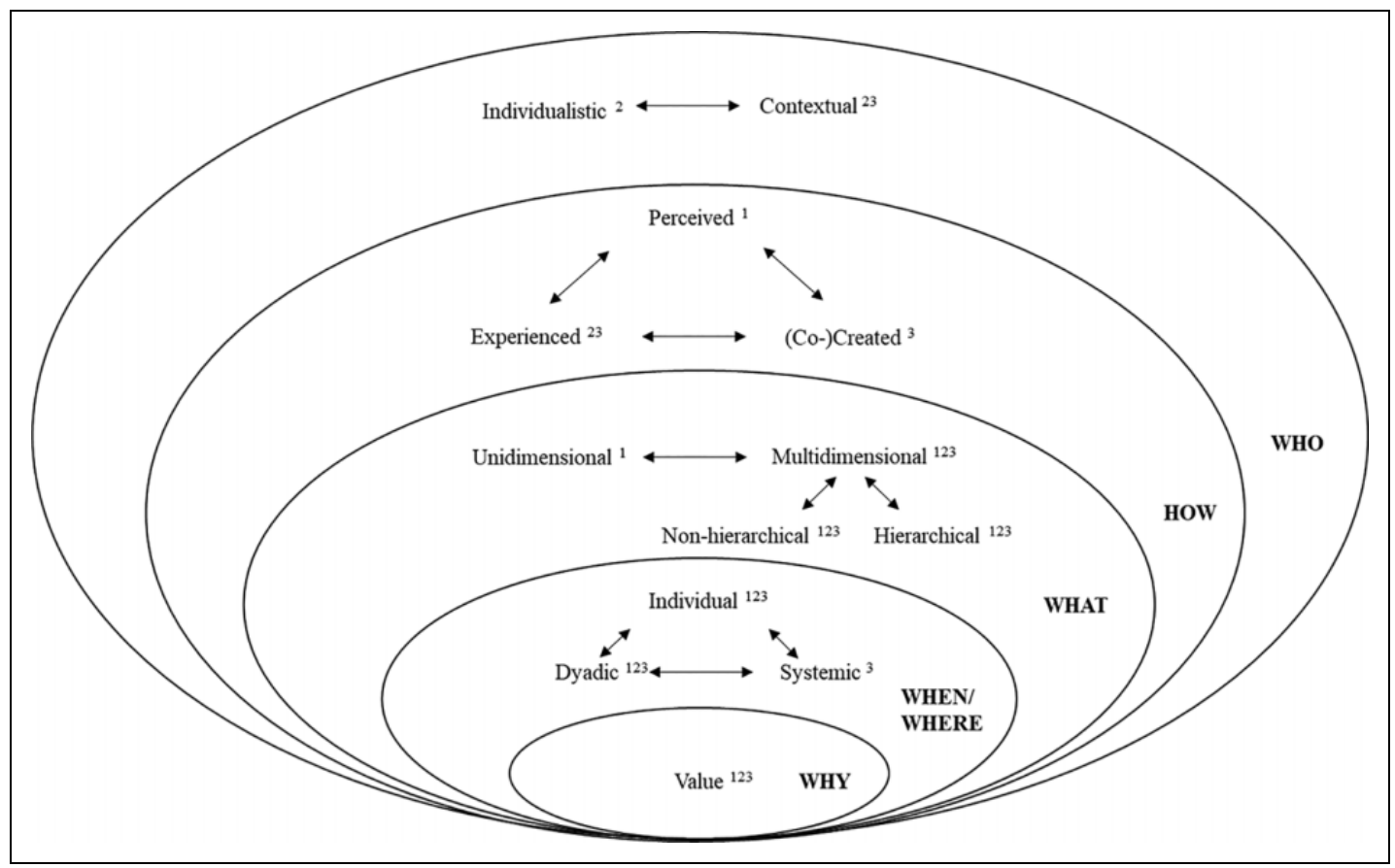

Figure I. Customer value framework.

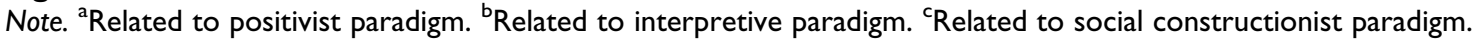

\section{Research Avenue I: The "Who": Identifying Sources of Value}

With regard to the sources of value, our review reveals that customers may value the same offerings differently, implying heterogeneity in - among other aspects - the personal drivers termed "human values," "personal values," or "consumer values" (Helkkula, Kelleher, and Philström 2012; Holbrook 1994). Yet, only a few positivist researchers embraced the notion that customer heterogeneity has an impact on value (Floh et al. 2014) and attempted to assess its connection to behavioral intentions. The paucity of research embracing the effects of customer heterogeneity is not surprising as, in its broadest sense, positivism refers to the theory of knowledge that asserts the pursuit of causal explanation through generalization. However, as an aggregate analysis of customer value, this approach fails to account for customer heterogeneity and could prompt erroneous parameter estimates in quantitative studies and suboptimal management decisions (Desarbo, Jedidi, and Sinha 2001). Future research would benefit from cross-fertilization between the positivist and interpretive research stream, as interpretive researchers have embraced customer heterogeneity with their individualistic conceptualizations of value (cf. Phase I in interpretive tradition). Future work may unravel how underexplored research populations such as children (Williams, Ashill, and Thirkell 2016), lowincome customers (Butler et al. 2016), and customers in developing societies (Chipp, Williams, and Lindgreen 2019) value different types of offerings, thereby also studying their sensemaking processes (cf. interpretive tradition) or value cocreation practices (cf. social constructionist tradition).
Accordingly, one could also ask: How can value perceptions of vulnerable or stigmatized customer groups be increased?

At the same time, interpretive and social constructionist research is called upon to consider heterogeneity in the contexts in which value perceptions emerge, as research in these traditions emphasizes the contextual nature of value (cf. Phase II in interpretive tradition and Phase II in social constructionist tradition). Virtually, all of the studies in our article deal with business-to-customer (B2C) contexts. What we did not cover in this article due to space limitations are the studies in business-tobusiness (B2B) contexts. However, a rich literature (e.g., Ellegaard, Medlin, and Geersbro 2014; Lepak, Smith, and Taylor 2007; Sánchez-Fernández et al. 2009) integrates this research and shows how value in B2B contexts differs from B2C contexts. Perhaps, the most developed and integrative research on B2B value was conducted by Macdonald, Kleinaltenkamp, and Wilson (2016). The research extends all previous work by investigating what represents value for customers from solutions over time. Most obvious in B2B research is the finding that the purchasing customer almost always includes both the collective customer (the buying or usage center) and each individual in the buying center (Huber and Kleinaltenkamp 2019). Future research could elaborate on the interplay between customer value at the individual and the collective level, thereby paying specific attention to the mechanisms that explain their (mis)alignment. Additionally, future research could focus on public contexts with governments as customers, which are also denoted as business-to-government (B2G) contexts (e.g., Beirão, Patrício, and Fisk 2017; Finkenstadt and Zeithaml 2020). Do customers in $\mathrm{B} 2 \mathrm{G}$ perceive value differently, how are value perceptions developed in for-profit versus nonprofit settings, 
Table 5. Road Map for Future Customer Value Research.

\begin{tabular}{|c|c|c|c|c|}
\hline $\begin{array}{l}\text { Research Avenue I: } \\
\text { "WHO": Identifying } \\
\text { Sources of Value }\end{array}$ & $\begin{array}{l}\text { Research Avenue 2. "HOW": } \\
\text { Capturing Value by Different } \\
\text { Research Methods }\end{array}$ & $\begin{array}{c}\text { Research Avenue 3: } \\
\text { "WHAT": Deciding on } \\
\text { Dimensionality and Hierarchy } \\
\text { of Value }\end{array}$ & $\begin{array}{c}\text { Research Avenue 4: } \\
\text { "WHEN/WHERE": Look- } \\
\text { ing for the Triggers for } \\
\text { Value }\end{array}$ & $\begin{array}{l}\text { Research Avenue 5: “WHY”: } \\
\text { Embedding Customer Value } \\
\text { in Nomological Networks }\end{array}$ \\
\hline $\begin{array}{l}\text { Individualistic } \\
\text { - Focus on } \\
\text { vulnerable or } \\
\text { stigmatized } \\
\text { populations } \\
\text { - Focus on link } \\
\text { with individual } \\
\text { context in which } \\
\text { customer } \\
\text { experiences } \\
\text { emerge } \\
\text { Contextual } \\
\text { - Focus on } \\
\text { individual and } \\
\text { collective value } \\
\text { in B2C, B2B, and } \\
\text { business-to- } \\
\text { government } \\
\text { Focus on society } \\
\text { as customer in } \\
\text { public markets } \\
\text { Focus on social, } \\
\text { market, and } \\
\text { environmental } \\
\text { context in which } \\
\text { customer } \\
\text { experiences } \\
\text { emerge }\end{array}$ & $\begin{array}{l}\text { Perceived } \\
\text { - Opt for mixed methods } \\
\text { when measuring } \\
\text { customer value in new } \\
\text { populations or contexts } \\
\text { Experienced } \\
\text { - Opt for repertory grid, } \\
\text { event-based narrative } \\
\text { inquiry, and design } \\
\text { thinking techniques to } \\
\text { reflect upon (possible } \\
\text { meanings of) customer } \\
\text { experiences } \\
\text { Co-created } \\
\text { Opt for case study, } \\
\text { (n)ethnography and } \\
\text { theory-in-use when } \\
\text { studying the emergence } \\
\text { of customer value and } \\
\text { value co-creation }\end{array}$ & $\begin{array}{l}\text { Dimensionality } \\
\text { - Contextualize the } \\
\text { dimensions of customer } \\
\text { value measures in } \\
\text { positivist research } \\
\text { - Consider context-specific } \\
\text { value dimensions in } \\
\text { interpretive or social } \\
\text { constructionist research } \\
\text { Hierarchy } \\
\text { - Focus on relative } \\
\text { importance of different } \\
\text { value dimensions, with } \\
\text { specific attention for } \\
\text { those associated with } \\
\text { technological } \\
\text { advancements and social/ } \\
\text { environmental issues } \\
\text { versus traditional ones }\end{array}$ & $\begin{array}{l}\text { Dyadic } \\
\text { - Focus on how the } \\
\text { value of a specific } \\
\text { brand or firm is } \\
\text { affected by contextual } \\
\text { changes } \\
\text { - Focus on how the } \\
\text { value perceptions of a } \\
\text { specific ecosystem } \\
\text { actor affect value } \\
\text { perceptions with } \\
\text { other ecosystem } \\
\text { actors } \\
\text { Systemic } \\
\text { - Focus on how } \\
\text { ecosystem actors that } \\
\text { customers meet along } \\
\text { their journey affect } \\
\text { value perceptions } \\
\text { - Focus on the interplay } \\
\text { between individual and } \\
\text { collective customer } \\
\text { value }\end{array}$ & $\begin{array}{l}\text { - } \begin{array}{l}\text { Focus on interplay } \\
\text { between customer } \\
\text { experience and customer } \\
\text { value }\end{array} \\
\text { - Focus on interplay } \\
\text { between customer value } \\
\text { and customer } \\
\text { engagement } \\
\text { - Focus on interplay } \\
\text { between customer value } \\
\text { and customer well-being } \\
\text { - Focus on interplay } \\
\text { between customer value } \\
\text { and business } \\
\text { performance, as } \\
\text { measured by customer } \\
\text { loyalty, customer lifetime } \\
\text { value, and customer } \\
\text { equity }\end{array}$ \\
\hline
\end{tabular}

and how do such potentially distinct value perceptions influence the dynamics of the settings? And to what extent do value perceptions of governments depend on the complexity of the societal systems in which they are embedded? And if so, do customers embedded in more complex societal systems and hence societies perceive value in more constrained ways, with their perceived value being dependent on other actors' value perceptions? What actors, for example, the individual, the group, or the system acting as customer (e.g., business network, societal group), are most influential and why?

Finally, future research can explore how and when individualistic and contextual variations in value perceptions are explained by customer experiences, as customer experiences are-in accordance with the touchpoint-context-qualities nomenclature (De Keyser et al. 2020) - a function of the individual context (i.e., the personal state of the customer), the social context (i.e., momentary conditions created by social relationships), the market context (i.e., conditions created by market-related actors like brands and firms), and the environmental context (i.e., broader externalities that are natural, economic, public, or political in nature). How can the individual, social, market, and environmental context in which customer experiences emerge affect customer value? And how can brands/firms manage the context and/or use contextual data to improve customer value?

\section{Research Avenue 2: The "How”: Capturing Customer Value Through Research Methods}

Many research methods are appropriate for investigating customer value. If the focus is on perceived value, researchers may rely on survey research with perceptual measures originating from the positivist tradition (see Table 1). Alternatively, researchers can also use evidence from qualitative studies in similar populations and/or contexts - which are summarized in Tables 2 and 3 - as a starting point for developing new scales. If the context in which customer value is measured has not yet been investigated, researchers may - in line with the studies of Andrews, Drennan, and Russell-Bennett (2012) or Huang et al. (2019) — opt for quantitative research preceded by qualitative research in the interpretive and social constructionist tradition. In this context, among the most promising research approaches are means-end chains and laddering (Macdonald, Kleinaltenkamp, and Wilson 2016; Reynolds and Gutman 1988; Zeithaml 1988). These approaches provide ways to explore situations 
Table 6. Sample Research Questions Resulting From the Five Research Avenues.

\begin{tabular}{|c|c|c|c|c|}
\hline $\begin{array}{l}\text { Research Avenue I: } \\
\text { "WHO": Identifying } \\
\text { Sources of Value }\end{array}$ & $\begin{array}{c}\text { Research Avenue 2: } \\
\text { “HOW”: Capturing Value } \\
\text { by Different Research } \\
\text { Methods }\end{array}$ & $\begin{array}{l}\text { Research Avenue 3: } \\
\text { "WHAT": Deciding on } \\
\text { Dimensionality and } \\
\text { Hierarchy of Value }\end{array}$ & $\begin{array}{l}\text { Research Avenue 4: } \\
\text { "WHEN/WHERE": } \\
\text { Looking for the Triggers } \\
\text { for Value }\end{array}$ & $\begin{array}{l}\text { Research Avenue 5: } \\
\text { "WHY": Embedding } \\
\text { Customer Value in } \\
\text { Nomological Networks }\end{array}$ \\
\hline $\begin{array}{l}\text { How can value } \\
\text { perceptions of } \\
\text { vulnerable or } \\
\text { stigmatized customer } \\
\text { groups be increased? } \\
\text { What mechanisms } \\
\text { explain the } \\
\text { (mis)alignment } \\
\text { between customer } \\
\text { value at the individual } \\
\text { and the collective } \\
\text { level? } \\
\text { How are value } \\
\text { perceptions developed } \\
\text { in for-profit versus } \\
\text { nonprofit settings? } \\
\text { To what extent do } \\
\text { value perceptions of } \\
\text { governments depend } \\
\text { on the complexity of } \\
\text { the societal systems in } \\
\text { which they are } \\
\text { embedded? } \\
\text { Do customers } \\
\text { embedded in more } \\
\text { complex societal } \\
\text { systems and hence } \\
\text { societies perceive } \\
\text { value in more } \\
\text { constrained ways? } \\
\text { How can brands/firms } \\
\text { manage the context } \\
\text { and/or use contextual } \\
\text { data to improve } \\
\text { customer value? }\end{array}$ & $\begin{array}{l}\text { - How and when does } \\
\text { customer value alter } \\
\text { along the customer } \\
\text { journey? } \\
\text { What is the association } \\
\text { between prepurchase } \\
\text { experiences and } \\
\text { perceptions of value } \\
\text { and customer } \\
\text { perceived value } \\
\text { following a purchase? } \\
\text { How do customer } \\
\text { experiences and } \\
\text { perceptions develop } \\
\text { across purchase } \\
\text { journeys with multiple } \\
\text { companies? } \\
\text { What characterizes the } \\
\text { historical, cultural, and } \\
\text { social context in which } \\
\text { value experiences and } \\
\text { perceptions emerge } \\
\text { along customer } \\
\text { journeys? } \\
\text { How do the value } \\
\text { perceptions of } \\
\text { consumers toward } \\
\text { specific touchpoint } \\
\text { affect customer } \\
\text { engagement toward the } \\
\text { brand or firm? }\end{array}$ & $\begin{array}{l}\text { Do new value } \\
\text { dimensions such as } \\
\text { ecological and } \\
\text { environmental value } \\
\text { relate to the core value } \\
\text { dimensions? } \\
\text { - How and when do new } \\
\text { value dimensions relate } \\
\text { to the core value } \\
\text { dimensions? } \\
\text { - How and under what } \\
\text { conditions do } \\
\text { technological } \\
\text { advancements trigger } \\
\text { different value facets? } \\
\text { Does technological } \\
\text { progress, and thereby } \\
\text { the magnitude in } \\
\text { technological change, } \\
\text { intensify customers' } \\
\text { experiences and hence } \\
\text { their value } \\
\text { perceptions? } \\
\text { How do these } \\
\text { technological } \\
\text { advancements } \\
\text { influence the } \\
\text { emergence of } \\
\text { customer value across } \\
\text { contexts? }\end{array}$ & $\begin{array}{l}\text { - How and when do } \\
\text { customer value } \\
\text { perceptions spill over } \\
\text { from one to other } \\
\text { actors in smart service } \\
\text { systems? } \\
\text { - How and when are } \\
\text { value assessments } \\
\text { affected by interactions } \\
\text { and dependencies } \\
\text { between different } \\
\text { actors in complex } \\
\text { systems? } \\
\text { - How and when do } \\
\text { different actors that } \\
\text { customers meet along } \\
\text { their journey to } \\
\text { achieve a specific } \\
\text { objective affect } \\
\text { customer value? } \\
\text { How and when do } \\
\text { individual value } \\
\text { perceptions and } \\
\text { resulting behavioral } \\
\text { intentions influence } \\
\text { group behavioral } \\
\text { intentions and vice } \\
\text { versa? } \\
\text { How do differences } \\
\text { among group members } \\
\text { influence group value } \\
\text { perceptions and buying } \\
\text { intentions? }\end{array}$ & $\begin{array}{l}\text { What is the } \\
\text { relationship between } \\
\text { customer value and } \\
\text { business performance, } \\
\text { as measured by } \\
\text { customer loyalty, } \\
\text { customer lifetime value, } \\
\text { and customer equity? } \\
\text { What is the } \\
\text { relationship between } \\
\text { facets of customer } \\
\text { value and innovation } \\
\text { throughput, output, } \\
\text { and also financial } \\
\text { performance? } \\
\text { What is the } \\
\text { relationship between } \\
\text { the way in which } \\
\text { customers perceive } \\
\text { value and their well- } \\
\text { being? } \\
\text { Under what conditions } \\
\text { is the positive or } \\
\text { negative relationship } \\
\text { between customer } \\
\text { value, or a lack thereof, } \\
\text { and negative feelings } \\
\text { such as anger } \\
\text { pronounced? } \\
\text { What role do loved } \\
\text { ones play in the } \\
\text { translation of customer } \\
\text { value into subjective } \\
\text { well-being? }\end{array}$ \\
\hline
\end{tabular}

where a need for qualitative understanding exists before quantitative effort can be undertaken.

Alternatively, researchers can use the Kelly Repertory Grid Technique (RGT). Developed by Kelly (1963) as an investigative tool, the RGT elicits from participants their knowledge about a construct by focusing on its difficult-to-articulate distinguishing characteristics (Macdonald, Kleinaltenkamp, and Wilson 2016). As such, RGT is a foundational process in extracting or making meaning of a customer's experience. Other techniques to reflect on the possible meaning of experiences with customers in a spontaneous and unsolicited naturalistic fashion include EBNIT (Helkkula, Kelleher, and Philström 2012) and design thinking techniques where complete customer journeys are visualized to elicit these experiences (Følstad and Kvale 2018). As acknowledged by the aforementioned researchers, these techniques allow researchers to co-construct meanings, experiences, and value perceptions with customers, which represents the social constructionist tradition.

If researchers want to investigate how customers co-create value in interactions with other actors, however, other techniques such as case study research (see Verleye 2019) and netnographic research (see Kelleher et al. 2019) are more appropriate. To capture the emergence of value-in-use and value-in-context, researchers can also rely on "casual layered analysis" of interview data (Ketonen-Oksi 2018). Further, Zeithaml et al. (2020) describe how theories-in-use (TIUs) can be used in situations such as these. A TIU is a person's mental model of how things work in a particular context and is a natural approach for creating theories that are specific to marketing-related issues. All stakeholders in marketingamong them managers, customers, employees, and public policy makers - have mental models that can be elicited by TIU research to surface interesting, novel theories and concepts. 
The TIU approach would be highly useful in studying cocreated value.

To gain insight into perceived, experienced, and/or cocreated value as a dynamic and time-dependent concept, studies would benefit by incorporating the recommendations for process research as formulated by Langley (1999). To further understand the time-dependent nature of customer value from a process research perspective, researchers can rely on both quantitative and qualitative data. Quantitative data generated by the use of mobile or wearable technologies, for instance, have the potential to address the question: How and when does customer value alter along the customer journey? Nevertheless, the difficulty of capturing the affective components of customer value over time should not be underestimated. Koller, Zauner, Floh and Foramitti (2011) offered a potential solution to the issue when advocating alternative approaches like videography. The EBNIT also allows a researcher to capture value dynamics in a qualitative way (Helkkula, Kelleher, and Philström 2012) as does using graphic depiction of customer encounters (Zeithaml et al. 2020) and/or visualization of complete journeys with design thinking tools (Følstad and Kvale 2018).

If researchers are able to comprehend customer value over time, they may also design experimental studies, diary studies, or other types of longitudinal research to address intriguing research questions. What is the association between prepurchase experiences and perceptions of value (also called desired customer value) and those held following a purchase (also called perceived customer value)? How do these experiences and perceptions develop across purchase journeys with multiple companies (De Keyser et al. 2020)? What characterizes the historical, cultural, and social context in which value experiences and perceptions emerge along customer journeys (Akaka and Vargo 2015)? To answer these questions, marketing scholars may also team up with researchers in history, political, and social sciences.

More frequent and sophisticated use of multiple research methods is necessary to achieve meaningful advances in this area. Laboratory studies using recent technological advances, for example, may be effectively combined with field studies to better capture a fuller and more complete array of constructs and processes than might be the case if only one method were used. For example, suppose a researcher wants to address the following question: How do the value perceptions of consumers toward their smart home applications affect customer engagement toward the smart home provider? Research in this context might examine the potential linkages between value perceptions and purchase intentions experimentally in the laboratory, while a netnographic analysis would allow the researcher to explore the linkages between value perceptions and word-of-mouth behaviors in social media postings longitudinally in the field. By combining the findings, researchers may generate a deeper understanding of customer value than if they relied on only a single methodology. Another well-known example of successfully combining qualitative and quantitative research approaches is the series of 12 studies on service quality conducted by Parasuraman, Zeithaml, and Berry (1985, 1988, 1994), each providing insight into a specific facet of service quality (also Zeithaml, Berry, and Parasuraman $(1988,1996)$.

\section{Research Avenue 3: The "What": Deciding on Dimensionality and Hierarchy}

As delineated in this review, a wide range of customer populations have been studied in an even broader range of contexts. Depending on the customer and context characteristics, researchers identified different numbers and types of value dimensions. As such, our review points to the benefits of contextualizing the dimensions of customer value measures. The dimensionality of customer value measures can be tailored to B2C, B2B, or business-to-government (B2G) contexts, as research shows that sufficient differences between $\mathrm{B} 2 \mathrm{C}$, B2B, and B2G settings exist (e.g., Beirão, Patrício, and Fisk 2017; Ellegaard, Medlin, and Geersbro 2014; Finkenstadt and Zeithaml 2020). Additionally, researchers can incorporate changes in the historical, social, and cultural context in customer value measures, such as technological advancements, social changes, environmental issues, and crises such as the new coronavirus pandemic. Recent research endeavors - often in the interpretive or social constructionist tradition-consider customer value in the context of online communities (Seraj 2012), collaborative consumption (Figueiredo and Scaraboto 2016), and energy efficiency (Butler et al. 2016). Yet, the consideration of these contextual changes in customer value measures may offer a sound basis for further bringing together positivist, interpretive, and social constructionist research.

Our review also shows that research has not paid much attention to contextual changes in the conceptualization of customer value. For instance, sustainable consumption is now a critical topic in the developed world, and awareness among consumers of imminent environmental and societal problems is increasing rapidly (Whitmarsh 2009). This growth in public awareness has prompted a rise in both theoretical and practical work on the factors associated with sustainable consumption (e.g., Butler et al. 2016; Koller, Floh, and Zauner 2011). Building on these insights from a positivist tradition, future research could ask whether new value dimensions such as ecological and environmental value relate to the core value dimensions in different product or service domains.

In a similar vein, recent technological advances indicate that experiential value could become more pivotal in the future. Experiential value has recently been conceptualized holistically in reference to quality of services, time, effort, and convenience (cognitive value); enjoyment, pleasure, and escapism (hedonic value); status, esteem, and social approval (social value); and trust and privacy (ethical value) and it has been shown to predict purchase intention (Varshneya and Das 2017). Research could answer important questions revolving around experiential value in relation to the core value dimensions. Further, future research might consider exploring how and under what conditions technological advancements trigger different value facets more generally. To date, researchers have 
used mixed methods to explore the creation of customer value in mobile marketing (Andrews, Drennan, and Russell-Bennett 2012; Huang et al. 2019) and netnographic analyses to better understand the emergence of customer value in online communities (e.g., Loane, Webster, and D'Allesandro 2015; Seraj 2012), but artificial intelligence contributes to the launch of a wide range of technological innovations - including but not limited to smart products, service robots, and other types of conversational agents (technological actors designed to engage in conversations with human beings; Robinson et al. 2020). Does technological progress, and thereby the magnitude in technological change, intensify customers' experiences and hence their value perceptions (Varshneya, Das, and Khare 2017)? How do these technological advancements influence the emergence of customer value across contexts?

Beyond exploring how contextual changes-like social/ environmental issues and technological innovation - affect the dimensionality of customer value, future research could also explore the way in which different dimensions relate to one another, which relate to the hierarchy. Here, researchers could ask: How and when do new value dimensions - such as ecological, environmental, and experiential value - relate to the core value dimensions in different product or service domains? Ecological value, for instance, may be more important for some customers than other facets of value, depending on the magnitude of change in the social and cultural context in which the different product or services or experiences are demanded. Only after such work is conducted, can we answer at what point in time customers change their behaviors or pay attention to contextual changes.

\section{Research Avenue 4: "When/Where": Looking for the Triggers of Value}

Early customer value research focused on how customers value products such as cars or consumer goods (e.g., Monroe and Chapman 1987; Sheth, Newman, and Gross 1991; Zeithaml 1988) or services such as tourism, financial services, and mobile entertainment (e.g., Petrick 2004; Pura 2005; Roig et al. 2006). In recent years, researchers and practitioners moved away from this dyadic perspective on customer value by exploiting the complementary roles of product and service elements. Companies that once focused solely on their product offering now increasingly depend on bundling products and services to secure competitive advantage and vice versa (Mittal, Kumar, and Tsiros 1999). It follows that scholars have a duty to examine customer value from a systemic perspective, especially in situations where the consumption and evaluation of both product and the service subsystems depend heavily on the performance of their counterparts (Mittal, Kumar, and Tsiros 1999). Recently, Floh et al. (2017) examined the consumption system around wireless telecommunications and identified major differences in value dimensions (functional, economic, social, or emotional) that spill over from product to service and vice versa. Building on these insights, future research could ask whether this may also hold for the emergence of customer value in smart service systems, as these systems encompass digital services delivered to or via smart products (Wünderlich et al. 2015). If so, how and when?

Despite research progress, the manner in which customer value is associated with product and service (hybrid) subsystems and how value assessments are affected by the interactions and dependencies between them needs further clarification, as would their effects on behavioral intentions. Such future value research could contribute to research in computer science and engineering that is largely focused on the technical features of smart products, neglecting "a muchneeded re-conceptualization of how value can be co-created and captured from these technologies" (Beverungen et al. 2019 , p. 8). In turn, the value literature has largely ignored the transformative potential that smart products offer. Given the rise of impersonal service encounters, with service robots taking over in multiple situations, one needs to ask: How will this new context shape the customer value?

Moreover, future research may also explore customer value in interactions with the multitude of actors involved in new consumption systems, thereby advancing the work on value creation in service ecosystems, which recently gained momentum in interpretive and social constructionist research (e.g., Jaakkola and Alexander 2014). For instance, do different ecosystem actors that customers meet along their journey to achieve a specific objective - whether or not owned by brands or firms - affect value perceptions? If so, how and when? Several researchers, for instance, emphasize that social media networks or communities (e.g., brand communities or celebrity fan groups) along with individual influencers have become central influencers of customer value (De Keyser et al. 2020; de Valck, van Bruggen, and Wierenga 2009; Kelleher et al. 2019). This type of influencer may generate substantial community effects, ultimately affecting the value perceived by individual customers (Maas and Graf 2008). Thus, future research should focus on whether and how different types of actors in ecosystems affect their value perceptions. Longitudinal studies might provide answers to important questions, among the most pressing issues in the social media marketing context. How do individual value perceptions and resulting behavioral intentions influence group behavioral intentions? Is this influence symmetrical for customer value or not? How do group value perceptions and buying intentions influence the individual? How do differences among group members influence group value perceptions and buying intentions? How does such diversity arise among the members of the community or network and how can it be managed?

\section{Research Avenue 5: The "Why": Embedding Customer Value in Nomological Networks}

Prior research that analyzes potential antecedents of customer value has typically emphasized concepts such as quality, price, or sacrifice (Gallarza, Gil-Saura, and Holbrook 2011). Although it is clear that other variables such as brand perceptions (Brodie, Whittome, and Brush 2009), product 
characteristics (Gale and Wood 1994), perceived risk (Sweeney, Soutar, and Johnson 1999), and esthetics (Walters and Lancaster 1999) are potential sources of value (or lack thereof), the manner in which they create value is not as clear (see also Gallarza, Gil-Saura, and Holbrook 2011; Parasuraman 1997). Indeed, research on the complex interplay of customer value and individual and situational context continuously introduces new concepts - such as different types of social support (Parkinson et al. 2019) and other value-enhancing and valueconstraining mechanisms (e.g., Kelleher et al. 2019). Thus, it is important to gain insight into the nomological network in which customer value is embedded. What are the antecedents, consequences, and associated mechanisms of customer value? One path to these ends is to synthesize extant research findings by engaging in meta-analytical research endeavors, thereby opting for reconceptualizations of the findings (Doyle 2003).

In a similar vein, researchers can engage in meta-analytical research to better understand the relationship between customer value and business performance, as measured by customer loyalty, customer lifetime value, and customer equity (Payne and Holt 2001). Recent research, for instance, points out that the relationships between customer value and its relational consequences - such as loyalty - appear to be more complex than originally assumed (e.g., Leroi-Werelds et al. 2014). Previous research showed that customer value leads to loyalty or repurchase (Sánchez-Fernández and Iniesta-Bonillo 2006) and ultimately to actual behavior (Bolton and Drew 1991). Floh et al. (2014), in turn, showed that the direct effects of customer value on loyalty differ in magnitude depending on the relevance customers attribute to specific (i.e., affective vs. cognitive) value dimensions. Building upon this line of research, future research can explore neuronal networks or nonlinear causal relationships among the variables (Maas and Graf 2008). Alternatively, researchers can - in line with a process theory approach-focus on the interplay between customer value and business performance over time. For instance, which dimensions and facets of customer value affect which dimensions of performance, innovation throughput, output, and also financial performance? In turn, which dimensions of business performance affect which dimensions and facets of customer value? How do such influences arise and how can they be managed?

Finally, future research might engage in theorizing about the relationship between the way in which customers perceive value and their well-being (e.g., McColl-Kennedy et al. 2017), with subjective well-being gaining increasing attention as an ultimate goal of our societies. Here, it would be relevant to explore how customer value affects different components of well-being, such as cognitive well-being (e.g., life satisfaction) and positive and negative affective well-being and vice versa. Does the perception of value lead to feelings of happiness and satisfaction? Or does satisfaction, happiness lead to value perceptions of customers? Under what conditions is the positive or negative relationship between customer value, or a lack thereof, and negative feelings such as sadness and anger pronounced? What role do loved ones play in the translation of customer value into subjective well-being?

Thus, by researching the economic and noneconomic implications, preconditions, and contingencies of customer value, the acceptance/relevance of these concepts could be strengthened, both in theory and in practice. A profound understanding of the conceptual and measurement-related characteristics of customer value may also aid in applying it more extensively within management initiatives involving customer value as proposed by Verhoef and Lemon (2013).

\section{Conclusion}

Customer value is a pivotal issue in organizations and among customers, educators, the mainstream media, practitioners, and, increasingly, in scholarly research journals (see, e.g., Eggert, Kleinaltenkamp, and Kashyap 2019; Leroi-Werelds 2019). A vast but surprisingly disjointed body of literature exists that relates directly or indirectly to customer value. This literature addresses customer value from positivist (see, e.g., Zauner, Koller, and Hatak 2015), interpretive (see, e.g., Helkkula, Kelleher, and Philström 2012), and social constructionist paradigms (e.g., Chipp, Williams, and Lindgreen 2019). Because of the differing perspectives, considerable variation in conceptualization and measurement exists in extant research. We believe that these research endeavors can be viewed as complementary, in that perceived customer value is a multifaceted concept. Therefore, we suggested future directions in the customer value area that integrate the differences in a relevant and interesting way. A key concern relates to its link with everyday practices to manage value perceptions of all individuals and organizations. First, managers can use the content of this research article - in particular Tables 2-4-to reflect upon the dimensions along which they aim to create value. Additionally, this research offers managers an impetus for exploring and/or assessing value perceptions of their offerings by proposing a wide range of qualitative and quantitative research techniques. A combination of techniques is likely to be necessary to gain insight into the multifaceted and dynamic nature of value perceptions, which is a key takeaway for managers. Finally, this research also recommends that managers consider the historical, social, and cultural context in which value perceptions emerged. As customer activity becomes more global and interconnected, the standards on which evaluative judgments hinge are likely to change continuously and faster than ever. For managers, the exploration and/or assessment of perceived value is therefore not a onetime phenomenon (Sánchez-Fernández and Iniesta-Bonillo 2007); rather, it must be seen as an ongoing assessment using a mixture of both qualitative and quantitative approaches within an evolving consumer relationship. As a consequence, we hope that firms consider integrating systematic value tracking within their marketing activities. We also hope that scholars move the field further by building on the avenues discussed in this article. 


\section{Declaration of Conflicting Interests}

The author(s) declared no potential conflicts of interest with respect to the research, authorship, and/or publication of this article.

\section{Funding}

The author(s) received no financial support for the research, authorship, and/or publication of this article.

\section{ORCID iD}

Valarie A. Zeithaml (D https://orcid.org/0000-0003-4693-6069

Katrien Verleye (D) https://orcid.org/0000-0002-6727-4175

\section{Supplemental Material}

Supplemental material for this article is available online.

\section{Note}

1. Service-dominant logic researchers focused on the co-creative process (e.g., Vargo and Lusch 2016) and its associated value cocreation practices (e.g., McColl-Kennedy et al. 2017). To date, a number of review studies have focused on synthesizing the (value) co-creation literature (e.g., Alves, Fernandes, and Raposo 2016; Bharti, Agrawal, and Sharma 2015; Kohtamäki and Rajala 2016; Leroy, Cova, and Salle 2013; Ranjan and Read 2016) and linking value co-creation to perceived customer value (Gummerus 2013; Lindgreen et al. 2012).

\section{References}

Akaka, Melissa Archpru and Stephen L. Vargo (2015), "Extending the Context of Service: From Encounters to Ecosystems," Journal of Services Marketing, 29 (6-7), 453-462.

Alves, Helena, Cristina Fernandes, and Mário Raposo (2016), "Value Co-Creation: Concept and Contexts of Application and Study," Journal of Business Research, 69 (5), 1626-1633.

Andrews, Lynda, Judy Drennan, and Rebekah Russell-Bennett (2012), "Linking Perceived Value of Mobile Marketing with the Experiential Consumption of Mobile Phones," European Journal of Marketing, 46 (3/4), 357-386.

Azmat, Fara, Ahmed Ferdous, Ruth Rentschler, and Emma Winston (2018), “Arts-Based Initiatives in Museums: Creating Value for Sustainable Development," Journal of Business Research, 85, 386-395.

Babin, Barry J., William R. Darden, and Mitch Griffin (1994), "Work and/or Fun: Measuring Hedonic and Utilitarian Shopping Value," Journal of Consumer Research, 20 (4), 644-656.

Baxter, Roger (2009), "Reflective and Formative Metrics of Relationship Value: A Commentary Essay," Journal of Business Research, 62 (12), 1370-1377.

Becker, Larissa and Elina Jaakkola (2020), "Customer Experience: Fundamental Premises and Implications for Research," Journal of the Academy of Marketing Science, 48, 630-648. doi:10.1007/ s11747-019-00718-x.

Beirão, Gabriela, Lia Patrício, and Raymond P. Fisk (2017), "Value Cocreation in Service Ecosystems: Investigating Health Care at the Micro, Meso, and Macro Levels." Journal of Service Management, 28 (2), 227-249.
Beverungen, Daniel, Oliver Müller, Martin Matzner, Jan Mendling, and Jan Vom Brocke (2019), "Conceptualizing Smart Service Systems," Electronic Markets, 29 (1), 7-18.

Bharti, Kumkum, Rajat Agrawal, and Vinay Sharma (2015), "Literature Review and Proposed Conceptual Framework," International Journal of Market Research, 57 (4), 571-604.

Blocker, Christopher P. and Andrés Barrios (2015), "The Transformative Value of a Service Experience," Journal of Service Research, 18 (3), 265-283.

Boksberger, Philipp E. and Lisa Melsen (2011), "Perceived Value: A Critical Examination of Definitions, Concepts and Measures for the Service Industry," Journal of Services Marketing, 25 (3), 229-240.

Bolton, Ruth N. and James H. Drew (1991), "A Multistage Model of Customers' Assessments of Service Quality and Value," Journal of Consumer Research, 17 (4), 375-384.

Brady, Michael and Christopher J. Robertson (1999), “An Exploratory Study of Service Value in the USA and Ecuador," International Journal of Service Industry Management, 10 (5), 469-486.

Brodie, Roderick, Helge Löbler, and Julia Fehrer (2019). Evolution of Service-Dominant Logic: Towards a Paradigm and Metatheory of the Market and Value Cocreation? Industrial Marketing Management, 79, 3-12.

Brodie, Roderick, James R. M. Whittome, and Gregory J. Brush (2009), "Investigating the Service Brand: A Customer Value Perspective," Journal of Business Research, 62(3), 345-355.

Butler, Katherine, Ross Gordon, Kate Roggeveen, Gordon Waitt, and Paul Cooper (2016), "Social Marketing and Value in Behaviour? Perceived Value of Using Energy Efficiently among Low Income Older Citizens." Journal of Social Marketing, 6 (2), 144-168.

Carlson, Jamie, Philip J. Rosenberger, and Mohammed M. Rahman (2015), "Cultivating Group-Oriented Travel Behaviour to Major Events: Assessing the Importance of Customer-Perceived Value, Enduring Event Involvement and Attitude towards the Host Destination," Journal of Marketing Management, 31 (9-10), 1065-1089.

Chandler, Jennifer D. and Stephen L. Vargo (2011), "Contextualization and Value-in-Context: How Context Frames Exchange," Marketing Theory, 11 (11), 35-49.

Chipp, Kerry, Patricia Williams, and Adam Lindgreen (2019), "Value-in-Acquisition: An Institutional View," European Journal of Marketing, 55 (11), 2373-2396.

Chiu, Chao-Min, Eric T.G. Wang, Yu-Hui Fang, and Hsin-Yi Huang (2014), “Understanding Customers' Repeat Purchase Intentions in B2C e-Commerce: The Roles of Utilitarian Value, Hedonic Value and Perceived Risk," Information Systems Journal, 24 (1), 85-114. Creswell, John W. and Cheryl N. Poth (2018), Qualitative Inquiry \& Research Design Choosing among 5 Approaches. Thousand Oaks, CA: Sage.

Cronin, J. Joseph, Michael K. Brady, and G. Tomas M. Hult (2000), "Assessing the Effects of Quality, Value, and Customer Satisfaction on Consumer Behavioral Intentions in Service Environments," Journal of Retailing, 76 (2), 193-218.

Cronin, J. Joseph, Michael K. Brady, Richard R. Brand, Roscoe Hightower, and Donald J. Shemwell (1997), “A Cross-Sectional Test of 
the Effect and Conceptualization of Service Value." Journal of Services Marketing, 11 (6), 375-391.

Crotty, Michael (1998), The Foundations of Social Research: Meaning and Perspective in the Research Process. Thousand Oaks, CA: Sage.

De Keyser, Arne, Katrien Verleye, Katherine Lemon, Tim Keiningham, and Phil Klaus (2020), "Moving the Customer Experience Field Forward: Introducing the Touchpoints, Context, Qualities (TCQ) Nomenclature," Journal of Service Research. doi: 10. 1177/1094670520928390.

de Ruyter, Ko, Martin Wetzels, Jos Lemmink, and Jan Mattson (1997), "The Dynamics of the Service Delivery Process: A Value-Based Approach," International Journal of Research in Marketing, 14 (3), 231-243.

Desarbo, Wayne S., Kamel Jedidi, and Indrajit Sinha (2001), "Customer Value Analysis in a Heterogeneous Market," Strategic Management Journal, 22 (9), 846-857.

de Valck, Kristine Gerrit, H. van Bruggen, and Berend Wierenga (2009), "Virtual Communities: A Marketing Perspective," Decision Support Systems, 47(3), 185-203.

Dodds, William B., Kent B. Monroe, and Dhruv Grewal (1991), "Effects of Price, Brand, and Store Information on Buyers' Product Evaluations," Journal of Marketing Research, 28 (3), 307-319.

Dodds, William B. and Kent B. Monroe (1985), "The Effect of Brand and Price Information on Subjective Product Evaluations," in Advances in Consumer Research, E. C. Hirschman and M. B. Holbrook, eds. Provo, UT: Association for Consumer Research, 85-90.

Doyle, Lynn H. (2003), "Synthesis through Meta-Ethnography: Paradoxes, Enhancements, and Possibilities," Qualitative Research, 3 (3), 321-344.

Eggert, Andreas, Michael Kleinaltenkamp, and Vishal Kashyap (2019), "Mapping Value in Business Markets: An Integrative Framework," Industrial Marketing Management, 79, 13-20.

El-Adly, Mohammed I. and Riyad Eid (2016), “An Empirical Study of the Relationship between Shopping Environment, Customer Perceived Value, Satisfaction, and Loyalty in the UAE Malls," Journal of Retailing and Consumer Services, 31, 217-227.

Ellegaard, Chris, Christopher J. Medlin, and Jens Geersbro (2014), "Value Appropriation in Business Exchange-Literature Review and Future Research Opportunities," Journal of Business \& Industrial Marketing, 29 (3), 185-198.

Fazal-e-Hasan, Syed M., Hormoz Ahmadi, Gary Mortimer, Martin Grimmer, and Louise Kelly (2018), "Examining the Role of Consumer Hope in Explaining the Impact of Perceived Brand Value on Customer-Brand Relationship Outcomes in an Online Retailing Environment," Journal of Retailing and Consumer Services, 41, 101-111.

Figueiredo, Bernardo and Daiane Scaraboto (2016), “The Systemic Creation of Value through Circulation in Collaborative Consumer Networks," Journal of Consumer Research, 43 (4), 509-533.

Finkenstadt, Daniel J. and Valarie A. Zeithaml (2020), "Perceived Service Quality and Perceived Value in Business-to-Government Knowledge-Based Services," working paper, University of North Carolina at Chapel Hill, Chapel Hill, NC.
Floh, Arne, Monika Koller, Alexander Zauner, and Christoph Teller (2017), "Multiple Value Dimensions Spill-Over-An Experimental Approach in a Consumption System Comprising a Product and a Service," Journal of Consumer Behaviour, 16 (4), 352-362.

Floh, Arne, Alexander Zauner, Monika Koller, and Thomas Rusch (2014), "Customer Segmentation Using Unobserved Heterogeneity in the Perceived-Value-Loyalty-Intentions Link," Journal of Business Research, 67 (5), 974-982.

Følstad, Asbjørn and Knut Kvale (2018), "Customer Journeys: A Systematic Literature Review," Journal of Service Theory and Practice, 28 (2), 196-227.

Gale, Bradely T. and Robert C. Wood (1994), Managing Customer Value: Creating Quality and Service that Customers Can See. New York: Free Press.

Gallarza, Martina G., Francisco Arteaga, Giacomo Del Chiappa, Irene Gil-Saura, and Morris B. Holbrook (2017), "A Multidimensional Service-Value Scale Based on Holbrook's Typology of Customer Value: Bridging the Gap between the Concept and Its Measurement," Journal of Service Management, 28 (4), 724-762.

Gallarza, Martina G., Irene Gil-Saura, and Morris B. Holbrook (2011), "The Value of Value: Further Excursions on the Meaning and Role of Customer Value," Journal of Consumer Behaviour, 10 (4), 179-191.

Gallarza, Martina G. and Irene Gil-Saura (2006), "Value Dimensions, Perceived Value, Satisfaction and Loyalty: An Investigation of University Students' Travel Behaviour," Tourism Management, 27 (3), 437-452.

Gioia, Dennis A., Kevin G. Corley, and Aimee L. Hamilton (2013), "Seeking Qualitative Rigor in Inductive Research: Notes on the Gioia Methodology," Organizational Research Methods, 16 (1), 15-31.

Graf, Albert and Peter Maas (2008), "Customer Value from a Customer Perspective: A Comprehensive Review," Journal Für Betriebswirtschaft, 58 (1), 1-20.

Grönroos, Christian and Johanna Gummerus (2014), “The Service Revolution and Its Marketing Implications: Service Logic vs Service-Dominant Logic," Managing Service Quality, 24 (3), 206-229.

Grönroos, Christian and Païva Voima (2013), "Critical Service Logic: Making Sense of Value Creation and Co-Creation," Journal of the Academy of Marketing Science, 41 (2), 133-150.

Gummerus, Johanna (2013), "Value Creation Processes and Value Outcomes in Marketing Theory: Strangers or Siblings?" Marketing Theory, 13 (1), 19-46.

Heinonen, Kristina (2006), "Temporal and Spatial E-Service Value," International Journal of Service Industry Management, 17 (4), 380-400.

Helkkula, Anu, Carol Kelleher, and Minna Pihlström (2012), "Characterizing Value as an Experience: Implications for Service Researchers and Managers," Journal of Service Research, 15 (1), 59-75.

Hernandez-Ortega, Blanca, Joaquin Aldas-Manzano, Carla RuizMafe, and Silvia Sanz-Blas (2017), "Perceived Value of Advanced Mobile Messaging Services: A Cross-Cultural Comparison of Greek and Spanish Users," Information Technology \& People, 30 (2), 324-355. 
Hirschman, Elizabeth C. and Morris B. Holbrook (1982), "Hedonic Consumption: Emerging Concepts, Methods and Propositions," Journal of Marketing, 46 (3), 92-101.

Holbrook, Morris B. (2006), "Consumption Experience, Customer Value, and Subjective Personal Introspection: An Illustrative Photographic Essay," Journal of Business Research, 59 (6), 714-725.

Holbrook, Morris B. (1999), Consumer Value: A Framework for Analysis and Research (Routledge Interpretive Marketing Research Series, 1). London: Routledge.

Holbrook, Morris B. (1994), The Nature of Customer Value, An Axiology of Services in the Consumption Experience. Thousand Oaks, CA: Sage.

Holbrook, Morris B. and Elizabeth C. Hirschman (1982), "The Experiential Aspects of Consumption: Consumer Fantasies, Feelings, and Fun," Journal of Consumer Research, 9 (2), 132-140.

Huang, Lijuan, Jian Mou, Eric WK See-To, and Jongki Kim (2019), "Consumer Perceived Value Preferences for Mobile Marketing in China: A Mixed Method Approach," Journal of Retailing and Consumer Services, 48, 70-86.

Huber, Frank and Michael Kleinaltenkamp (2019), "Changes of Organizational Usage Processes: Attitudes, Behaviors and Consequences," Marketing-ZFP Journal of Research and Practice, 40 (3), 17-30.

Huber, Frank, Andreas Herrmann, and Stephan C. Henneberg (2007), "Measuring Customer Value and Satisfaction in Services Transactions, Scale Development, Validation and Cross-Cultural Comparison," International Journal of Consumer Studies, 31 (6), 554-564.

Jaakkola, Elina and Matthew Alexander (2014), "The Role of Customer Engagement Behavior in Value Co-Creation: A Service System Perspective," Journal of Service Research, 17(3), 247-261.

Jarvis, Cheryl Burke, Scott B. MacKenzie, and Philip M. Podsakoff (2003), "A Critical Review of Construct Indicators and Measurement Model Misspecification in Marketing and Consumer Research," Journal of Consumer Research, 30 (2), 199-218.

Jiang, Kai, Sherriff Ting-Kwong Luk, and Silvio Cardinali (2018), "The Role of Pre-Consumption Experience in Perceived Value of Retailer Brands: Consumers' Experience from Emerging Markets," Journal of Business Research, 86, 374-385.

Jutbring, Henrik (2018), "Social Marketing through a Music Festival: Value Perceived by Festival Visitors Who Reduced Meat Consumption," Journal of Social Marketing, 8 (2), 237-256.

Kelleher, Carol, Hugh N. Wilson, Emma K. Macdonald, and Joe Peppard (2019), "The Score Is Not the Music: Integrating Experience and Practice Perspectives on Value Co-Creation in Collective Consumption Contexts," Journal of Service Research, 22 (2), 120-138.

Kelly, George A. (1963), A Theory of Personality: The Psychology of Personal Constructs. London: Norton.

Ketonen-Oksi, S. (2018), "Creating a Shared Narrative: The Use of Causal Layered Analysis to Explore Value Co-Creation in a Novel Service Ecosystem," European Journal of Futures Research, 6 (5), $1-12$.

Kohtamäki, Marko and Risto Rajala (2016), "Theory and Practice of Value Co-Creation in B2B Systems," Journal of Business Research, 56, 4-13.
Koller, Monika, Arne Floh, and Alexander Zauner (2011), "Further Insights into Perceived Value and Consumer Loyalty: A 'Green' Perspective," Psychology \& Marketing, 28 (12), 1154-1176.

Koller, Monika, Alexander Zauner, Arne Floh, and Camillo Foramitti (2011), "Being Connected-Perceived Customer Value in the Smartphone Age," Advances in Consumer Research, 39, 675.

Komulainen, Hanna, Saila Saraniemi, Pauliina Ulkuniemi, and Marianne Ylilehto (2018), "End-Customer Value Restructuring the Financial Service Supply Chain," Marketing Intelligence \& Planning, 36 (6), 709-720.

Koronaki, Eirini, Antigone G. Kyrousi, and George G. Panigyrakis (2018), "The Emotional Value of Arts-Based Initiatives: Strengthening the Luxury Brand-Consumer Relationship," Journal of Business Research, 85, 406-423.

Koskela-Huotari, Kaisa and Jaakko Siltaloppi (2020), "Rethinking the Actor in Service Research: Toward a Processual View of Identity Dynamics," Journal of Service Theory and Practice. doi:10.1108/ JSTP-11-2018-0245.

Langley, A. (1999). Strategies for Theorizing from Process Data. Academy of Management Review, 24 (4), 691-710.

Lepak, David P., Ken G. Smith, and M. Susan Taylor (2007), "Value Creation and Value Capture: A Multilevel Perspective," Academy of Management Review, 32 (1), 180-194.

Leroi-Werelds, Sara (2019), “An Update on Customer Value: State of the Art, Revised Typology, and Research Agenda," Journal of Service Management, 30 (5), 650-680.

Leroi-Werelds, Sara, Sandra Streukens, Michael K. Brady, and Gilbert Swinnen (2014), “Assessing the Value of Commonly Used Methods for Measuring Customer Value: A Multi-Setting Empirical Study," Journal of the Academy of Marketing Science, 42 (4), 430-451.

Leroy, Julie, Bernard Cova, and Robert Salle (2013), “Zooming in vs Zooming Out on Value Co-Creation: Consequences for BtoB Research," Industrial Marketing Management, 42 (7), 1102-1111.

Lin, Chien-Hsin, Peter J. Sher, and Hsin-Yu Shih (2005), "Past Progress and Future Directions in Conceptualizing Customer Perceived Value," International Journal of Service Industry Management, 16 (4), 318-336.

Lin, Chinho and Watcharee Lekhawipat (2015), "How Customer Expectations Become Adjusted after Purchase," International Journal of Electronic Commerce, 20 (4), 443-469.

Lindgreen, Adam, Martin K. Hingley, David B. Grant, and Robert E. Morgan (2012), "Value in Business and Industrial Marketing: Past, Present, and Future," Industrial Marketing Management, 41 (1), 207-214.

Loane, Susan S., Cynthia M. Webster, and Steven D'Alessandro (2015), "Identifying Consumer Value Co-Created through Social Support within Online Health Communities," Journal of Macromarketing, 35 (3), 353-367.

Maas, Peter and Albert Graf (2008), "Customer Value Analysis in Financial Services," Journal of Financial Services Marketing, 13 (2), 107-120.

Macdonald, Emma K., Michael Kleinaltenkamp, and Hugh N. Wilson (2016), "How Business Customers Judge Solutions: Solution Quality and Value in Use," Journal of Marketing, 80 (3), 96-120. 
Martelo-Landroguez, Silvia, Carmen Barroso-Castro, and Gabriel C. Cepeda (2014), "The Cycle of Customer Value: A Model Integrating Customer and Firm Perspectives," Journal of Business Economics and Management, 16 (2), 467-481.

Mathwick, Charla, Naresh Malhotra, and Edward Rigdon (2001), "Experiential Value: Conceptualization, Measurement and Application in the Catalog and Internet Shopping Environment," Journal of Retailing, 77 (1), 39-56.

McColl-Kennedy, Janet R., Suellen J. Hogan, Lars Witell, and Hannah Snyder (2017), "Cocreative Customer Practices: Effects of Health Care Customer Value Cocreation Practices on Well-Being," Journal of Business Research, 70, 55-66.

Mittal, Vikas, Pankaj Kumar, and Michael Tsiros (1999), “AttributeLevel Performance, Satisfaction, and Behavioral Intentions over Time: A Consumption-System Approach," Journal of Marketing, 63 (2), 88-101.

Mochon, Daniel and Janet Schwartz (2020), “The Importance of Construct Validity in Consumer Research," Journal of Consumer Psychology, 30 (1), 208-214.

Monroe, Kent B. and Joseph D. Chapman (1987), "Framing Effects on Buyers' Subjective Product Evaluations," Advances in Consumer Research, 14 (1), 193-197.

Oliver, Richard L. (2010), Satisfaction: A Behavioral Perspective on the Consumer, 2nd ed. New York: Routledge.

Oyedele, Adesegun and Penny M. Simpson (2018), "Streaming Apps: What Consumers Value," Journal of Retailing and Consumer Services, 41, 296-304.

Parasuraman, A. Parsu (1997), "Reflections on Gaining Competitive Advantage through Customer Value," Journal of the Academy of Marketing Science, 25 (2), 154-161.

Parasuraman, A. Parsu, Valarie A. Zeithaml, and Leonard L. Berry (1994), "Reassessment of Expectations as a Comparison Standard in Measuring Service Quality: Implications of Future Research," Journal of Marketing, 58 (1), 111-124.

Parasuraman, A. Parsu, Valarie A. Zeithaml, and Leonard L. Berry (1988), "SERVQUAL: A Multiple-Item Scale for Measuring Service Quality," Journal of Retailing, 64 (1), 12-40.

Parasuraman, A. Parsu, Valarie A. Zeithaml, and Leonard L. Berry (1985), "A Conceptual Model of Service Quality and Its Implications for Future Research," Journal of Marketing, 49 (4), 41-50.

Parente, Eduardo S., Francisco J. Costa, and Aurio L. Leocádio (2015), "Conceptualization and Measurement of Customer Perceived Value in Banks," International Journal of Bank Marketing, 33 (4), 494-509.

Parkinson, Joy, Rory Francis Mulcahy, Lisa Schuster, and Heini Taiminen (2019), "A Transformative Value Co-Creation Framework for Online Services," Journal of Service Theory and Practice, 29 (3), 353-374.

Payne, Adrian and Sue Holt (2001), "Diagnosing Customer Value: Integrating the Value Process and Relationship Marketing," British Journal of Management, 12 (2), 159-182.

Petrick, James F. (2004), “The Roles of Quality, Value, and Satisfaction in Predicting Cruise Passengers' Behavioral Intentions," Journal of Travel Research, 42 (4), 397-407.
Petrick, James F. (2002), "Development of A Multi-Dimensional Scale for Measuring the Perceived Value of a Service," Journal of Leisure Research, 34 (2), 119-134.

Philström, Minna and Gregory J. Brush (2008), "Comparing the Perceived Value of Information and Entertainment Mobile Services," Psychology \& Marketing, 25 (8), 732-755.

Piyathasanan, Bhuminan, Christine Mathies, Martin Wetzels, Paul G. Patterson, and Ko De Ruyter K (2015), “A Hierarchical Model of Virtual Experience and Its Influences on the Perceived Value and Loyalty of Customers," International Journal of Electronic Commerce, 19 (2), 126-158.

Plewa, Carolin, Jillian C. Sweeney, and David Michayluk (2015), "Determining Value in a Complex Service Setting," Journal of Service Theory and Practice, 25 (5), 568-591.

Previte, Josephine, Rebekah Russell-Bennett, Rory Mulcahy, and Charmine Hartel (2019), "The Role of Emotional Value for Reading and Giving eWOM in Altruistic Services," Journal of Business Research, 99, 157-166.

Pura, Minna (2005), "Linking Perceived Value and Loyalty in Location-Based Mobile Services," Managing Service Quality, 15 (6), 509-538.

Ranjan, Kumar Rakesh and Stuart Read (2016), "Value Co-Creation: Concept and Measurement," Journal of the Academy of Marketing Science, 44 (3), 290-315.

Reynolds, Thomas J. and Jonathan Gutman (1988), "Laddering Theory, Method, Analysis, and Interpretation," Journal of Advertising Research, 28 (1), 11-31.

Rintamäki, Timo and Kaisa Kirves (2017), "From Perceptions to Propositions: Profiling Customer Value across Retail Contexts," Journal of Retailing and Consumer Services, 37, 159-167.

Robinson, Stacey, Chiara Orsingher, Linda Alkire, Arne De Keyser, Michael Giebelhausen, K. Nadia Papamichail, Poja Shams, and Mohamed S. Temerak (2020), "Frontline Encounters of the AI kind: An Evolved Service Encounter Framework," Journal of Business Research, 116, 366-376. doi:10.1016/j.jbusres.2019.08.038.

Roig, Carlos Fandos, Juan Javier Sanchez Garcia, Miguel Angel Moliner Tena, and Jaume Llorens Monzonis (2006), "Customer Perceived Value in Banking Services," International Journal of Bank Management, 24 (5), 266-283.

Ruiz, David Martín, Dwayne D. Gremler, Judith H. Washburn, and Gabriel Cepeda Carrión (2008), "Service Value Revisited: Specifying a Higher-Order, Formative Measure," Journal of Business Research, 61 (12), 1278-1291.

Sánchez-Fernández, Raquel, M. Ángeles Iniesta-Bonillo, and Morris B. Holbrook (2009), "The Conceptualisation and Measurement of Consumer Value in Services," International Journal of Market Research, 51 (1), 93-113.

Sánchez-Fernández, Raquel and M. Ángeles Iniesta-Bonillo (2007), "The Concept of Perceived Value: A Systematic Review of the Research," Marketing Theory, 7 (4), 427-451.

Sánchez-Fernández, Raquel and M. Ángeles Iniesta-Bonillo (2006), "Consumer Perception of Value: Literature Review and a New Conceptual Framework," Journal of Consumer Satisfaction, Dissatisfaction and Complaining Behavior, 19, 40-58. 
Seraj, Mina (2012), "We Create, We Connect, We Respect, Therefore We Are: Intellectual, Social, and Cultural Value in Online Communities." Journal of Interactive Marketing, 26 (4), 209-222.

Sheth, Jagdish N., Bruce I. Newman, and Barbara L. Gross (1991), "Why We Buy What We Buy: A Theory of Consumption Values," Journal of Business Research, 22 (2), 159-170.

Sweeney, Jillian C. and Geoffrey N. Soutar (2001), "Consumer Perceived Value: The Development of a Multiple Item Scale," Journal of Retailing, 77 (2), 203-220.

Sweeney, Jillian C, Geoffrey N. Soutar, and Lester W. Johnson (1999), "The Role of Perceived Risk in the Quality-Value Relationship: A Study in a Retail Environment," Journal of Retailing, 75 (1), 77-105.

Tommasetti, Aurelio, Orlando Troisi, and Massimiliano Vesci (2017), "Measuring Customer Value Co-Creation Behavior Developing a Conceptual Model Based on Service-Dominant Logic," Journal of Service Theory and Practice, 27 (5), 930-950.

Tynan, Caroline, Sally McKechnie, and Celine Chhuon (2010), "CoCreating Value for Luxury Brands," Journal of Business Research, 63 (11), 1156-1163.

Vargo, Stephen L. (2008), "Customer Integration and Value Creation: Paradigmatic Traps and Perspectives," Journal of Service Research, 11 (2), 211-215.

Vargo, Stephen L. and Robert F. Lusch (2016), "Institutions and Axioms: An Extension and Update of Service-Dominant Logic," Journal of the Academy of Marketing Science, 44 (1), 5-23.

Vargo, Stephen L. and Robert F. Lusch (2011), "It's All B2B ... and Beyond: Toward a Systems Perspective of the Market," Industrial Marketing Management, 40 (2), 181-187.

Vargo, Stephen L. and Robert F. Lusch (2008), "Service-Dominant Logic: Continuing the Evolution," Journal of the Academy of Marketing Science, 36 (1), 1-10.

Vargo, Stephen L. and Robert F. Lusch (2004), "Evolving to a New Dominant Logic for Marketing," Journal of Marketing, 68 (1), 1-17.

Varshneya, Geetika and Gopal Das (2017), "Experiential Value: Multi-Item Scale Development and Validation," Journal of Retailing and Consumer Services, 34, 48-57.

Varshneya, Geetika, Gopal Das, and Arpita Khare (2017), "Experiential Value: A Review and Future Research Directions," Marketing Intelligence \& Planning, 35 (3), 339-357.

Verhoef, Peter C. and Katherine N. Lemon (2013), "Successful Customer Value Management: Key Lessons and Emerging Trends," European Management Journal, 31 (1), 1-15.

Verhulst, Nanouk, Arne De Keyser, Anders Gustafsson, Poja Shams, and Yves Van Vaerenbergh (2019), "Neuroscience in Service Research: An Overview and Discussion of Its Possibilities," Journal of Service Management, 30 (5), 621-649.

Verleye, Katrien (2019), “Designing, Writing-Up and Reviewing Case Study Research: An Equifinality Perspective," Journal of Service Management, 30 (5), 549-576.
Verleye, Katrien (2015), "The Co-Creation Experience from the Customer Perspective: Its Measurement and Determinants," Journal of Service Management, 26 (2), 321-342.

Vyt, Dany, Magali Jara, and Gérard Cliquet (2017), "Grocery Pickup Creation of Value: Customers' Benefits vs. Spatial Dimension," Journal of Retailing and Consumer Services, 39, 145-153.

Walters, David and Geoff Lancaster (1999), "Value-Based Marketing and Its Usefulness to Customers," Management Decision, 37 (9), 697-708.

Wang, Yonggui, Hing Po Lo, Renyong Chi, and Yongheng Yang (2004), “An Integrated Framework for Customer Value and Customer-Relationship-Management Performance: A CustomerBased Perspective from China," Managing Service Quality, 14 (2/3), 169-182.

Waseem, Donia, Sergio Biggemann, and Tony Garry (2018), "Value Co-Creation: The Role of Actor Competence," Industrial Marketing Management, 70, 5-12.

Whitmarsh, Lorraine (2009), "Behavioural Responses to Climate Change: Asymmetry of Intentions and Impacts," Journal of Environmental Psychology, 29 (1), 13-23.

Williams, Janine, Nicholas Ashill, and Peter Thirkell (2016), "How Is Value Perceived by Children?" Journal of Business Research, 69 (12), 5875-5885.

Wünderlich, Nancy V., Kristina Heinonen, Amy Ostrom, Lia Patricio, Rui Sousa, Chris Voss, and Jos G. A. M. Lemmink (2015), “"'Futurizing” Smart Service: Implications for Service Researchers and Managers," Journal of Services Marketing, 29 (6-7), 442-447.

Zauner, Alexander, Monika Koller, and Isabella Hatak (2015), "Customer Perceived Value-Conceptualization and Avenues for Future Research," Cogent Psychology, 2 (1), 1-17.

Zboja, James J., Mary Dana Laird, and Adrien Bouchet (2016), "The Moderating Role of Consumer Entitlement on the Relationship of Value with Customer Satisfaction," Journal of Consumer Behaviour, 15 (3), 216-224.

Zeithaml, Valarie A. (1988), "Consumer Perceptions of Price, Quality, and Value: A Means-End Model and Synthesis of Evidence," Journal of Marketing, 52 (3), 2-22.

Zeithaml, Valarie A., Bernard J. Jaworski, Ajay K. Kohli, Kapil R. Tuli, Wolfgang Ulaga, and Gerald Zaltman (2020), "A Theoriesin-Use Approach to Building Marketing Theory," Journal of Marketing, 84 (1), 32-51.

Zeithaml, Valarie A., Leonard L. Berry, and A. Parsu Parasuraman (1996), "The Behavioral Consequences of Service Quality," Journal of Marketing, 60 (2), 31-46.

Zeithaml, Valarie A., Leonard L. Berry, and A. Parsu Parasuraman (1988), "Communication and Control Processes in the Delivery of Service Quality,” Journal of Marketing, 52 (2), 35-48.

\section{Author Biographies}

Valarie A. Zeithaml is the David Van Pelt Distinguished Professor Emerita at UNC and Honorary Doctor of BI Business School, Oslo, Norway. In addition to being a member of the inaugural cohort of AMA Fellows, her honors include the AMA Irwin/McGraw-Hill Distinguished Marketing Educator, the Paul D. Converse Award, the 
inaugural Berry-AMA Book Prize, and ten awards from marketing journals. Her citations exceed 220,000, including almost 30,000 for the value paper (Zeithaml 1988) mentioned in the current manuscript.

Katrien Verleye is an assistant professor of service innovation at the Center for Service Intelligence, Ghent University, Belgium. Within the domain of service innovation, her main research interests relate to customer engagement, co-creation, and legitimation in networks/ecosystems. Her research is published in the Journal of Service Research, Journal of Product Innovation Management, Journal of Business Research and others. She serves on three editorial boards.

Isabella Hatak is a professor and Chair of SME management and entrepreneurship at the University of St. Gallen in Switzerland. Her research focuses on the value-creating behavior of entrepreneurs including the influences upon that behavior as well as their outcomes in the form of business performance and well-being.
Monika Koller is associate professor at the Department of Marketing, WU Vienna University of Economics and Business, Austria. Her research focuses on perceived value in relation to products and services from a consumers ' perspective, including the investigation of relevant consequences and implications for applied marketing. Her main research interests in consumer behavior and consumer neuroscience relate to sensory perception and alternative methods to measure psychophysiological processes.

Alexander Zauner is professor and Chair of digital marketing and social media at Johannes Kepler University, Linz, Austria. He is also managing director of Business Gladiators $\mathrm{GmbH}$, a start-up that helps entrepreneurs succeed and find fulfillment in a digital world. His research interests are anchored in core topics of marketing including digital brand management, strategic communication, and consumer behavior. 